\title{
Myc and cell cycle control
}

\author{
Gabriel Bretones, M. Dolores Delgado and Javier León \\ Instituto de Biomedicina y Biotecnología de Cantabria (IBBTEC), CSIC-Universidad de \\ Cantabria-SODERCAN and Departamento de Biología Molecular, Universidad de Cantabria, \\ Santander, Spain.
}

\section{Correspondence}

Prof. Javier León. IBBTEC, C/Albert Einstein 22, PCTCAN, 39011-Santander, Spain. Tel: 34-942-201952.

Email: leonj@unican.es

\section{Key words}

Myc, cell cycle, proliferation, cyclin, Cdk, p21,p27.

\begin{abstract}
Soon after the discovery of the Myc gene (c-Myc), it became clear that Myc expression levels tightly correlate to cell proliferation. The entry in cell cycle of quiescent cells upon Myc enforced expression have been described in many models. Also, the downregulation or inactivation of Myc results in the impairment of cell cycle progression. Given the frequent deregulation of Myc oncogene in human cancer it is importat to dissect out the mechanisms underlying the role of Myc on cell cycle control. Several parallel mechanisms account for Myc-mediated stimulation of cell cycle. First, most of the critical positive cell cycle regulators are encoded by genes induced by Myc. These Myc target genes include Cdks, cyclins and E2F transcription factors. Apart from its direct effects on the transcription, Myc is able to hyperactivate cyclin/Cdk complexes through the induction of Cdk activating kinase (CAK) and Cdc25 phosphatases. Moreover, Myc antagonizes the activity of cell cycle inhibitors as p21 and p27 through different mechanisms. Thus, Myc is able to block p21 transcription or to induce Skp2, a protein involved in p27 degradation. Finally, Myc induces DNA replication by binding to replication origins and by upregulating genes encoding proteins required for replication initiation. Myc also regulates genes involved in the mitotic control. A promising approach to treat tumors with deregulated Myc is the synthetic lethality based on the inhibition of Cdks. Thus, the knowledge of the Mycdependent cell cycle regulatory mechanisms will help to discover new therapeutic approaches directed against malignancies with deregulated Myc.
\end{abstract}




\section{Introduction. Overview of cell cycle regulation.}

Progression through the cell cycle phases (G1, S, G2 and M) is under the control of a family of serine/threonine protein kinases. These kinases are heterodimers consisting of a catalytic subunit, the cyclin-dependent protein kinase (Cdk) and a regulatory subunit, the cyclin, required for Cdk to be active. To date, there are 21 genes encoding Cdks and 29 genes encoding cyclins in the human genome [1, 2]. Of these, Cdk1, 2, 4 and 6 and A, B, E, D-type cyclins are identified as the major regulators of the cell cycle. The expression of the Cdks remains relatively constant throughout the cell cycle whereas the cyclins are synthesized and destroyed in a cyclical fashion during cell cycle [3,4]. According to the "classical" cell cycle model (Fig. 1), at early G1-phase, mitogenic signals are first sensed and integrated by the expression of the D-type cyclins (D1, D2 and D3) that preferentially bind to and activate Cdk4 and Cdk6 [1, 5]. In the late G1-phase, Cdk2 is activated by binding to E-type cyclins (E1 and E2). The activation of G1-phase Cdks leads to the phosphorylation of retinoblastoma protein $(\mathrm{Rb})$ which allows the accumulation of E2F transcription factors. E2F transcriptional targets include genes encoding proteins required for S-phase [6, 7]. At S-phase, Cdk2 complexes with A-type cyclins A1 and A2. Cyclin A2 (cyclin A hereafter) is ubiquitously expressed whereas cyclin A1 is expressed almost exclusively during meiosis of male germline cells in the testes [8, 9]. Cyclin $A$ is expressed throughout the $S$ and $G 2$ phases and is required for DNA replication $[10,11]$. Finally, B-type cyclins (B1 and $B 2)$ together with Cdk1 drive cells through mitosis [1, 12]. There is also an additional cyclin $B$ (cyclin $B 3$ ), but as cyclin $A 1$, it is only expressed in germ cells of testis $[13,14]$. Degradation of $B$ cyclins by the APC/C complex is required to the output of mitosis $[11,15]$.

Nevertheless, systematic knockout of Cdk loci in the mouse germline has shown that Cdk2 [16, 17], Cdk4 [18, 19] and Cdk6 [20] are not essential for cell cycle progression of most cell types, although loss of each of these Cdks results in particular developmental defects. Moreover, concomitant loss of the interphase Cdk genes does not result in a general disturbance of the cell cycle in most cell types, being Cdk1 alone sufficient to drive the cell cycle progression [2, 21].

There is also significant redundancy among cyclins genes. Cyclins $\mathrm{D} 1^{-1 /} / \mathrm{D} 2^{-/ /} / \mathrm{D} 3^{-1-}$ mouse fibroblasts proliferate normally although they require increased mitogenic stimulation for cell cycle re-entry [22]. Like D-cyclins, E-type cyclins are largely dispensable for cell cycle progression of most embryonic cells [23, 24]. However, A-type cyclins are essential for cellcycle progression of hematopoietic and embryonic stem cells. Only when all A- and E-type cyclins genes are deleted, cell division is inhibited, suggesting that both types of cyclins play redundant roles in cell cycle progression [25]. Finally, cyclin B1 but not B2 loss results in early embryonic lethality [26]. In summary, from all the cyclins that regulate the canonical cell cycle, cyclin A2 and B1 appear to carry out unique functions, suggesting that together with Cdk1 are the "basic core elements" of the cell-cycle machinery [27, 28].

Cdks are subjected to negative regulation by Cdk inhibitory proteins (CKIs). Based on their sequence similarity and structure, CKls are divided into two protein families: the INK4 (Inhibitors of Cdk4) and the CIP/KIP (Cdk Interacting Protein/Kinase Inhibitory Protein) families $[29,30]$. The INK4 family comprises $\mathrm{p} 16^{\mathrm{INK} 4 \mathrm{~A}}, \mathrm{p} 15^{\mathrm{INK} 4 \mathrm{~B}}, \mathrm{p} 18^{\mathrm{INK} 4 \mathrm{C}}$ and $\mathrm{p} 19^{\mathrm{INK} 4 \mathrm{D}}$. These inhibitors bind to free Cdk4/6 and inhibit their kinase activity, interfering with their association to D-type cyclins and distorting the ATP binding site. Its ectopic expression arrests the cell cycle in G1phase (reviewed in $[29,30]$ ). The CIP/KIP family consists of three members: p21 ${ }^{\mathrm{CIP} 1}$ (Cdk Interacting Protein 1), p2 $7^{\mathrm{KIP} 1}$ (Kinase Inhibitory Protein 1) and $\mathrm{p} 57^{\mathrm{KIP} 2}$ (Kinase Inhibitory Protein 2). They bind to a broader spectrum of cyclin/Cdk complexes already formed, inhibiting their activities. These complexes include cyclin A-E/Cdk2, cyclin D/Cdk4-6 and cyclin A-B/Cdk1 heterodimers. Therefore they are able to inhibit progression at every cell cycle phase.

Human Myc gene family is composed of MYC, MYCN and MYCL1. MYC (also called c$M Y C$ ) encodes for Myc, which is an oncogenic transcription factor of the helix-loop-helix/leucine zipper protein family. Activation of transcription by Myc depends on formation of heterodimeric complexes with Max proteins. Myc-Max heterodimers bind to DNA sequences called E-boxes in 
the regulatory regions of its targets genes and recruit transcriptional coactivators. However Myc has also the ability to repress genes although the mechanism are less well known (for recent reviews see [31-34]. Myc is found deregulated in nearly half of human solid tumors and leukemia, and appears frequently associated with tumor progression [35-37]. Although it is likely that the three Myc genes exert similar effects on cell cycle this review will focus on Myc, which is the most ubiquitously expressed of the Myc genes, the more frequently deregulated in cancer and, as a consequence, the most studied Myc gene with regard to the cell cycle control.

\section{Myc levels correlate with cell proliferation}

Soon after the discovery of Myc gene it was recognized that Myc mRNA and protein expression closely correlated with cell proliferation rates. This was first reported at the mRNA level in quiescent lymphocytes and rodent fibroblasts in which Myc mRNA underwent a rapid induction within $2 \mathrm{~h}$ after stimulation with mitogenic lectins [38-40]. Thus, Myc gene was dubbed as "immediate early" response gene. Later on, Myc upregulation was also described in response to growth factors, which occur through both transcriptional and post-transcriptional mechanisms [41]. Further studies showed that this induction depends on the transit from quiescence into the proliferative state, while in continuously cycling cells, Myc gene is transcribed at similar rates in all cell cycle phases, as shown in fibroblasts $[42,43]$.

The mechanism for the up-regulation of Myc in quiescent cells stimulated with mitogens or serum is not completely known, but the data supports a relevant role for the Ras/Raf/Mek/Erk cascade in Myc upregulation [44]. The precise mechanism of how this cascade activates MYC expression remains to be established, but it likely involves the activation of transcription factors as Elk or Ets1-2 [45]. Myc is also upregulated upon the activation of other kinases, as reported for Janus kinases (Jak1 and Jak2) [46, 47], Src [48], v-Abl or Bcr-Abl [49, 50] or Akt [51, 52].

Consistently, the response to antiproliferative cytokines as transforming growth factor $\beta$ (TGF $\beta$ ) or interferon- $\gamma$ results in Myc down-regulation [53-56]. The repression of Myc by TFG $\beta$ is mediated by a repressive transcription factors complex of Smad4, p107 and E2F4/5 [57, 58]. In a parallel avenue of data, it was soon recognized that in cell culture models of differentiation, Myc was down-regulated as the cells undergo terminal differentiation associated to proliferation arrest. This was originally observed in erythroleukemia cells [59-61] and later on in other cellular models of different cell types (reviewed in [62]).

\section{Myc overexpression induces cell cycle progression in quiescent cells}

In agreement with the tight correlation between proliferation rates and Myc levels, the enforced Myc expression in quiescent cells is sufficient to mediate cell cycle entry, whereas inhibition of Myc expression causes cycling cells to withdraw from the cell cycle. This was observed in early experiments where Myc protein was transfected or microinjected into mouse fibroblasts [63, 64]. High Myc levels achieved upon transfection or retroviral transduction in cycling mammalian cells result in a reduced requirement for growth factors, block exit from the cell cycle, accelerate cell division, and increase cell size [65-67]. The same effects have been reported for Drosophila cells [68] and chick embryo cells [69]. The ectopic expression of Myc protein achieved by transfection or retroviral infection is able to induce S-phase in otherwise quiescent cells. This was elegantly confirmed using conditional Myc-estrogen receptor (MycER) chimeras, where Myc activation by the hormone induces cells to enter S-phase and undergo mitosis in the absence of external factors [70].

Another model that demonstrates the relevant role of Myc in cell cycle is the human lymphoblastoid P493.6, cell line, which carries a conditional Myc allele (tet-off system) and does not express endogenous Myc [71]. In these cells the proliferation rates, the fraction of cells in Sphase, and the cell size increases in a dose-dependent manner in response to increasing Myc levels [72]. Moreover, the genes regulated by serum stimulation and Myc were compared in this model and it was found that not a single Myc-induced gene was induced by serum to a similar extent. Thus, serum is not able to replace Myc in the regulation of proliferation-related genes 
and viceversa [73]. Interestingly induction of Myc in the absence of serum does not result in proliferation but increases the cell size, protein synthesis and glycolytic metabolism, indicating that cell cycle progression and increase in cell size are separate effects of Myc [71].

\section{Myc downregulation impairs cell cycle progression and mitogenic response}

Consistently with the enhanced proliferation observed upon Myc overexpression, the downregulation or biochemical inactivation of Myc results in defective cell cycle re-entry of quiescent cells. Thus, Myc antisense oligonucleotides prevent S-phase entry in human lymphoid and myeloid cells [74, 75]. Similarly, transfection and microinjection experiments also show that dominant negative Myc mutants (with deletions of the $\mathrm{N}$-terminal transactivation domain) impair the DNA synthesis induced by serum or SV40 large T antigen [76, 77].

It was soon recognized that the decrease in Myc levels by antisense RNA results in slow proliferation [78]. Later on, numerous studies showed the decrease in cell proliferation rate upon transfection or siRNAs or short.hairpin constructs for Myc. A systematic study in 23 cell lines with short-hairpin-mediated depletion of Myc revealed that in normal cells and some tumor-derived cell lines the arrest takes place at the G0/G1 phase, but in other tumor-derived cell lines the arrest occurs at G2/M [79]. The reason for this difference is not clear, but it may depend on concomitant alterations of oncosuppressors p16, Rb or p53 in the tumor cells [79].

An indirect proof of the role of Myc in cell cycle progression is the fact that Mxd proteins (Mxd1, Mxi1, Mxd3, Mxd4 and Mnt), which bind to Myc-binding sites and antagonize Myc transcriptional activity, inhibit cell proliferation (reviewed in [80-82]). Cell cycle arrest is also observed upon the enforced expression of MadMyc, a dominant-negative Myc mutant contaning the DNA binding and dimerization domains of Myc and the trans-repression domain of Mxd1 (also called Mad1). This effect is rescued by the co-expression of Myc [83, 84]. Expression of this mutant also abrogates the upregulation of serum-induced genes such as CCNB1 (cyclin B1) when starved cells are re-stimulated with serum [85].

Whereas all the above data indicate that a certain Myc level seems to be necessary for active proliferation, Myc is not strictly required for cell cycle completion, as at least some cell types can divide without Myc. Epiblast deletion of Myc in mouse embryos shows that Myc is not required for proliferation and development of most tissues in the early embryo (up to midgestation, E11.5) [86]. However, the effect of Myc deletion cannot be studied in cells derived from $\mathrm{Myc}^{-/}$embryos as these cells are outgrown by cells overexpressing N-Myc or L-Myc. This problem was elegantly overcome by disruption of both $M y c$ alleles in Rat1 fibroblasts. No mRNA for N-Myc or L-Myc is detected in these cells $[87,88]$. These Myc-deficient cells are viable and do grow, although very slowly, with reduced Cdk4,6 and Cdk2 activities and with an elongated G1 and G2-phases [89, 90]. Similarly, Myc-deficient B lymphocytes generated by targeted recombination proliferate very slowly when they are mitogenically stimulated with anti-CD40 and IL4 [91]. Extensive screens with retroviral cDNA libraries on Myc-deficient Rat1 cells have revealed that only Myc and N-Myc are able to rescue the slow-growth phenotype of the cells. Although a particular combination of two or more genes may have passed untested in the screening, the data suggest that there are no functional equivalents of Myc proteins and that there are no Myc-activated genes that alone can substitute for Myc in control of cell proliferation [92].

At least three mechanisms collaborate to explain the promoting activity of Myc in cell cycle progression described above: (i) transcriptional activation of genes whose products are required for cell cycle progression, (ii) impairment of p21 and p27 activities, and (iii) stimulation of DNA replication. These mechanisms will be analyzed in the next sections of this review.

\section{Myc target genes related to cell cycle control}

Given the Myc effects on proliferation previously mentioned, it is not surprising that cell cycle related genes were among the first described as "Myc target genes" (cyclin D2, cyclin E1, Cdk4, Cdc25A, E2F1) (reviewed in [32, 93, 94]). Prominent examples of these Myc target genes 
as revealed in these and other studies, as well as the model where the effect is observed, are summarized in Table 1. The Table also shows the binding of Myc to the corresponding gene promoter by chromatin immunoprecipitation. The list includes pivotal cell cycle control genes as Cdks, cyclins and CIP/KIP proteins. Recent reports show that Myc functions as a general amplifier of already active genes but with low expression levels [95, 96]. However, the mRNA levels of some of the genes shown in Table 1 are dramatically increased upon activation of Myc in quiescent cells of different model systems, suggesting that Myc differentially upregulates at least some cell cycle control genes with respect to other genes.

The genome-wide gene expression studies show that Myc regulates a staggering number of genes, around 1000 in most models [85, 97-102]. Thus, it is not surprising that many of these genes are related to cell cycle. In a gene expression profiling study in rat fibroblasts it has been shown that Myc overexpression regulated 37 out of 87 genes classified as belonging to the "cell cycle pathway" in the KEGG (Kyoto Encyclopedia of Genes and Genomes) [103]. In another study in mouse fibroblasts, about 300 genes have been identified as genes induced by serum in a Myc-dependent manner (i.e., not induced when Myc gene is silenced by RNA interference). Almost $80 \%$ of these genes have Myc bound to the promoter (i.e., in the interval $\pm 1 \mathrm{~kb}$ from the transcription start site) [104]. This number of genes represents a small fraction (5.5\% in the mentioned study) of all those bound by Myc, which is estimated to be the $10-20 \%$ of all genes by genome-wide studies [101, 105-111]. However, the affinity of Myc for these promoters is higher than the mean affinity for other Myc-targeted promoters. The ontology analysis revealed that only a minority of genes are involved in cell cycle control, whereas the majority of the genes are involved in other processes, including nucleotide biosynthesis, ribosome biogenesis, DNA replication and RNA control [104]. It is of note that many of the Myc-target genes are involved in de novo nucleotide biosynthesis, protein synthesis and energetic metabolism [97, 112-115]. Given that the cell must duplicate its size along the cell cycle, synthesizing all cell components as well as all the nucleotides to be used for DNA replication, it is clear the importance of Myc in the biology of a cycling cell.

Transcription factors of the E2F family are critical for G1-S progression [7, 116]. E2F1, $\mathrm{E} 2 \mathrm{~F} 2$, and E2F3 are induced by ectopic Myc expression in quiescent cells (Table 1) and Myc fails to induce S-phase in E2F2 ${ }^{-/-}$or E2F3 ${ }^{-/-}$cells $[117,118]$. Moreover, Myc binds to E2F1-3 promoters and the E-box in their promoters are required for full induction of E2F2 and E2F3 expression in response to mitogens $[118,119]$ (Table 1). In contrast, E2F1 deficiency does not impair Myc-induced S-phase progression and Myc-induced tumorigenicity in vivo [117, 120]. In addition, E2F1 is negatively regulated by two microRNAs (miR-17 and miR-20a, from the miR17-92 cluster) that are induced by Myc $[121,122]$ suggesting a regulatory mechanism through which Myc simultaneously activates E2F1 transcription and limits its translation. On the other hand, Myc promoter contains an E2F site which is important for Myc expression [123, 124]. However, the E2F site on Myc promoter does not seem to bind E2F proteins but a different transcription factor not yet identified [125]. Therefore, the precise mechanism of the Myc-E2F functional interaction awaits further study.

Besides the induction of the mir-17-92 cluster described above, Myc activity has a major effect as a repressor of miRNAs that target critical cell cycle regulators. These miRNAs include let-7 family members, miR-15a/16-1, miR-26a or miR-34a. Key cell-cycle control factors targeted by let-7 miRNAs include Cdc25a, Cdk6, cyclin A, cyclin D1 D2 and D3 [126-128]. miR34a inhibit expression of cell-cycle regulators such as Cdk4, Cdk6, cyclin E2 and E2Fs, while miR-15a/16-1 regulates Cdk6, E2F3, cyclin D1 and D3; and miR-26a represses cyclin D2 and E2 (reviewed in $[127,129])$. Both induction and repression of specific miRNAs by Myc influences all levels of the cell cycle regulatory machinery and facilitates transit through the cell cycle.

\section{Myc induces Cdks activity}


Myc-induced cell proliferation is generally associated with an increase in Cdk2, Cdk4 and Cdk6 activities to regulate G1/S-phase progression [89, 130-132] (Fig. 1). Importantly, Myc is able to augment the levels of active cyclin/Cdk complexes not only through the transactivation of the cyclin and/or Cdk genes but also by induction of Cdk activating kinase (CAK) or phosphatases (Cdc25 proteins) and/or repression of a Cdk inhibitory kinase (Wee1). These mechanisms are described below.

\subsection{Cdk genes induction.}

Among all Cdk genes, CDK4 seems to be the most clear Myc target gene, as it appears in most gene profiling studies (Table 1). The upregulation of Cdk4 has been observed after Myc expression in several species (human and mouse) and cell types (endothelial cells, fibroblasts, $\mathrm{B}$ cells and epithelial cells), albeit at different degrees. The regulation of CDK4 by Myc seems to be direct, as suggested by the conservation of Myc binding sites in the Cdk4 promoter among different cell models and by the ability of Myc to activate the promoter in reporter assays [133]. Myc also binds to Cdk6 gene in ChIP-on-chip analysis in rat fibroblasts and Burkitt lymphoma cells (Daudi cells). Accordingly, Cdk6 mRNA is induced by Myc in these models, although no information about changes in Cdk6 protein expression have been reported [103, 108]. In addition, Myc binding sites to Cdk6 gene have been also identified in mouse embryonic stem cells [106, 107] and HeLa cells [134].

The role of Myc in regulating Cdk2 expression is complex and there are conflicting data in the literature. It has been described that Myc overexpression induces Cdk2 at mRNA and protein level and that silencing of Myc decreases Cdk2 expression in human lung cells [135]. In contrast, Cdk2 expression is not affected by Myc activation in Rat1 cells [136] and no Myc binding to Cdk2 promoter has been described or found by the ENCODE project (ChIP-seq data deposited in the University of California Santa Cruz browser, http://genome.ucsc.edu/). Finally, Myc binding to Cdk1 promoter has been identified by ChIP in mouse embryonic stem cells [107] and in several human cell lines (ChIP-seq data drom ENCODE project in http://genome.ucsc.edu/). Intriguingly, Myc alone is not sufficient to induce the Cdk1 expression [137] and requires cooperation with other proteins as Ras [138] or cyclin C [137].

\subsection{Cyclin genes induction.}

There is some controversy about cyclin D1 regulation by Myc, and it seems to depend on the cell model. Myc is reported to increase cyclin D1 protein in mouse fibroblasts $[139,140]$ and rat fibroblasts (Rat1-MycER cells) [139, 141]. On the other hand, it has also been described that MycER activation downregulates cyclin D1 in the same Rat1-MycER cell model $[132,142]$. In agreement with the latter result, constitutive expression of Myc also represses cyclin D1 mRNA in BALB/c-3T3 mouse fibroblasts [142, 143] via core promoter elements, antagonizing USFmediated transactivation [143]. In other Rat1-derived cell lines, cyclin D1 expression was not affected by Myc expression [136, 144].

In contrast to the conflicting data on cyclin D1, it is stablished that cyclin D2 gene (CCND2) is a bona fide Myc target gene. Myc binds to the human cyclin D2 promoter in vivo via a single highly conserved E-box element $[145,146]$, induces histone acetylation in a TRRAPdependent manner and induces cyclin D2 mRNA and protein expression [146]. Therefore, Myc promotes G1-phase cell cycle progression in part through the transcriptional up-regulation of the cyclin D2 gene [146]. Myc also increases cyclin D2 protein in mouse fibroblasts [139, 140]. Cyclin D3 can be also considered a Myc target gene as it is upregulated in mouse embryo fibroblasts in response to Myc expression [140] and Myc binds to its promoter (Table1). Moreover, Myc-mediated induction of cyclin D3 has been reported in embryonic lung fibroblasts while Myc silencing downregulates it in lung cancer cells [135].

Myc also upregulates cyclin E1 and E2 genes (Table 1). In rat fibroblasts, Myc activation induces cyclin E1 gene transcription and the increase in cyclin E1 mRNA, leading to the activation of cyclin E/Cdk2 complexes and induction of DNA synthesis [131]. Moreover, Myc can induce cyclin E1 expression indirectly through the induction of E2F transcription factors [147]. 
Increased cyclin E2 mRNA expression has also been observed in human lung fibroblasts and carcinoma cells overexpressing Myc [135]. Consistently with these findings, Myc binds to cyclin E1 and E2 promoters in human B cells [101]. Cyclin E-type mRNA and protein have also been found upregulated in response to Myc activation in rat fibroblast [132, 136, 142]. In Myctransformed cells separated according to cell size by centrifugal elutriation, cyclin E/Cdk2 kinase activity was upregulated not only in late $\mathrm{G} 1 / \mathrm{S}$, as in the normal counterparts, but throught the entire cell cycle [132]. Taken together the effect of Myc on Cdk4/6, Cdk2, D and Etype cyclins, a picture emerges in which Myc upregulates G1 cyclins/Cdks activity. The importance of this Myc effect is underlined by the observation that the $\mathrm{G} 1$ arrest induced by a Myc dominant-negative mutant (MadMyc, section 4) is rescued by ectopic expression of cyclin E/CDK2 and cyclin D1/Cdk4 [83].

Increased cyclin A mRNA and protein expression is observed in Rat1 fibroblasts with conditional (MycER) or constitutive Myc expression [132, 136, 142, 148, 149]. Furthermore, cyclin A seems to be essential for Myc-dependent progression of cell cycle in human lung fibroblasts and lung carcinoma cells [135]. Myc binding to CCNA2 promoter (but not to CCNA1 promoter) is detected by ChIP-on-ChIP and ChIP-seq in several human cell lines [134] and data from ENCODE project) (Table 1).

Finally, It has been shown that Myc binds to human cyclin B1 promoter containing a functional Myc binding site in lung cancer cells [150]. Myc binding to cyclin B1 promoter has been confirmed by ChIP in HeLa cells [85]. Moreover it has been described that Myc and loss of p53 cooperate to induce cyclin B1 mRNA and protein in Rat1 cells and 32D myeloid cells stably transfected with a Myc expression vector [151].

\subsection{Induction of CAK activity.}

In addition to Cdk induction and cyclin binding, the complete activation of cyclin/Cdk complexes requires several phosphorylation and dephosphorylation events at different residues of Cdk proteins. Cyclin/Cdk complexes are activated by CAK (Cdk activating kinase), which phosphorylates the Cdk T loop [152, 153]. Thus, CAK is responsible for the activating phosphorylation of Thr161 in Cdk1, Thr172 in Cdk4 and Thr177 in Cdk6 which are structurally equivalent to Thr160 in Cdk2 [154]. CAK is composed of three subunits: Cdk7 (the catalytic subunit), cyclin $\mathrm{H}$ and MAT1. Myc increases CAK activity in rat fibroblasts increasing Cdk7, cyclin $\mathrm{H}$, and MAT1 protein expression through augmented mRNA translation but not by Mycmediated transcriptional activation [155]. Nevertheless, Myc binding to CDK7 promoter has been shown in mouse ES cells [106] (Table 1). In agreement, Cdk7 protein expression is reduced in $\mathrm{Myc}^{-/-}$rat cells $(\mathrm{HO15.19})[89,156]$. The CAK is also a subunit of TFIIH, one of the general transcription factors present in the RNA polymerase II preinitiation complex [154]. Myc recruits Cdk7 to the transcriptional start site, increases CAK activity and the concomitant phosphorylation on Ser5 of the C-terminal domain (CTD) of RNA polymerase II, a phosphorylation associated to initiation of transcription $[155,157]$.

\subsection{Induction of Cdc25 phosphatases.}

Cdks can also be regulated via inhibitory phosphorylations of two conserved residues near the N-terminus (Thr14 and Tyr15 in human Cdk1 and Cdk2) located within the ATP-binding site of the enzyme [153]. Tyr15 phosphorylation is carried out by Wee1 [158]. It has been described that both Myc [159] and N-Myc [160] induce miR-221, which has been shown to target Wee1 [161]. Thus, it is likely that Myc can repress Wee1 by induction of this microRNA, although further studies are required to confirm this hypothesis. miR-221 also affects multiple cancer pathways by modulating other mRNAs, including inhibition of Rb, p27 and p57 [161, 162]. Dephosphorylation of both residues are required for Cdk activation and cell cycle regulation, particularly at mitosis for the control of Cdk1 activation, and this is carried out by dual specific phosphatases of the Cdc25 family [152, 153]. Cdc25A has been proposed to be a Myc target gene [163] although no changes in Cdc25A mRNA or protein have been observed following 
Myc-ER activation in quiescent Rat1-fibroblasts and Cdc25A gene expression was unaffected in Myc $^{-/-}$cells $[88,131,132]$.

\section{Myc and $\mathrm{p} 21^{\mathrm{CIP1}}$}

As mentioned before, Myc represses the cyclin-dependent kinase inhibitor p21 ${ }^{\mathrm{CIP} 1 / \text { Waf1 }}$ (p21 hereafter). One of the first evidences came from human immortalized keratinocyte cells stably expressing Myc, where Myc inhibited TGF $\beta$-mediated repression of cell-cycle progression abolishing the induction of p21 expression [164]. Several mechanisms are used by Myc to repress p21 and are summarized in Fig. 2A. The most studied mechanism for Myc-mediated repression of p21 is through the initiator-binding transcription factor Miz-1. While Miz-1 stimulates transcription, the direct interaction with Myc transform this zinc-finger transcription factor into a transcriptional repressor $[165,166]$. This interaction blocks p21 induction by p53 and, as a consequence, Myc contributes to the initiation of apoptosis by p53 [167]. Moreover, through this mechanism Myc also blocks the p21-mediated differentiation of hematopoietic cells [168]. Furthermore, it has been described that Myc and Miz-1 form a ternary complex with the DNA methyltransferase DMNT3a and that DNA methylation is required for Myc-mediated repression of CDKN1A (p21). This suggest that Myc can silence p21 gene expression not only by passive Miz-1 functional interference but also by active recruitment of corepressor proteins [169].

There are additional mechanisms which allows Myc to repress p21 (Fig. 2A): (i) Myc triggers a transcriptional cascade by inducing the gene encoding the transcription factor AP4 (TFAP4), which binds to recognition motifs in the p21 promoter and mediates transcriptional repression of p21 [170]. (ii) Myc antagonized the induction of p21 mediated by oncogenic Ras [171]. p21 upregulation by Ras depends on SP1 and Myc interferes with SP1 transactivation of p21 promoter [171, 172]. (iii) Myc interacts with the histone demethylase KDM5B and with the transcription factor TFAP2C (AP2-gamma) forming a ternary complex that repress p21 transcription [173]. This implies a histone H3 demethylation mechanism for p21 repression. Therefore, both histone demethylation and DNA methylation seems to be required for Mycmediated repression of $p 21$. (iv) Finally, Myc induces the microRNA cluster miR-17-92, which includes miRNAs predicted to target p21 mRNA [159, 174, 175].

\section{Myc and $\mathrm{p} 27^{\mathrm{KIP} 1}$}

One of the most important targets of Myc in cell proliferation is the Cdk inhibitor p27. Myc accelerates cell proliferation rates, at least in part, through its ability to antagonize p27 activities in proliferation and differentiation [176, 177]. Accordingly, Myc-deficient cells show increased p27 protein levels [89, 91]. This is accomplished by several parallel mechanisms, summarized in Fig. 2B: (i) Myc suppresses p27 expression at transcriptional level in lymphoid and breast cancer cells $[178,179]$ (Table 1). (ii) Myc induces de miR-221 and miR-222 that leads to p27 mRNA silencing [159, 162]. Previous experiments have showed that miR-221 is able to induce proliferation targeting p27, both in vitro [162] and in vivo [180]. (iii) Myc induces cyclin $\mathrm{E}$ transcription directly or through the induction of E2F transcription factors, increasing the levels of cyclin E/Cdk2 complexes that functionally antagonize p27 by promoting G1/S transition.[130, 131, 176] (iv) Induction of cyclins D1 and D2, as well as their catalytic partners Cdk4 and Cdk6 by Myc, allows the assembly of cyclin D/Cdk4,6 complexes, which sequester p27 and relieve the inhibition of cyclin E/Cdk2 complexes [145, 181, 182]. (v) Myc induces the expression of several components of the $\mathrm{SCF}^{\mathrm{SKP} 2}$ ubiquitin ligase complex, the major complex that ubiquitinates p27. Thus, Myc induces Cul1 [183], Cks1 [184] and the F-box protein Skp2, the subunit involved in substrate selection and that recognizes Thr187-phosphorylated p27 [185]. This phosphorylation is required for p27 degradation by the proteasome [186-189]. Interestingly, Myc also stimulates the Thr187 phosphorylation of p27, likely through the upregulation of Cyclin E/Cdk2 $[185,190]$. Since SCF $^{\text {SKP2 }}$ is the most important ubiquitin ligase 
for p27 degradation [191, 192], Myc appears to be a major regulator of p27 levels in cell nuclei. The general picture describes Myc as a potent inhibitor of p27 activity as cell cycle brake. This is important given that p27 expression is frequently downregulated in human cancer and low p27 levels associate to poor prognosis [193, 194]. However, impairment of p21 and p27 function is not the only pro-proliferative mechanism elicited by Myc, as mouse embryo fibroblasts deficient for both p27 and the related p21 are still responsive to stimulation by Myc and can be arrested in $\mathrm{G} 1$ by a dominant negative mutant of Myc [195].

\section{Myc, DNA replication and mitosis}

Myc induces genes directly related to DNA replication. The origin recognition complex (ORC) is a highly conserved six subunits protein complex essential for the initiation of the DNA replication in eukaryotic cells. A number of ORC genes as ORC1, ORC2, ORC4 and ORC5 have been identified as Myc targets in mouse fibroblasts and human $B$ cells $[101,103]$. The gene encoding for Cdc6 (Cell Division Cycle 6), a protein required for the initiation of replication, has also been found to be a Myc target gene [101, 108]. Myc also induces genes encoding MCM (minichromosome maintenance) proteins as MCM3, MCM4 and MCM5 [101, 105, 108], which are essential for correct DNA replication initiation and elongation. Besides the gene expression induction described above, it has been also reported that Myc stimulates DNA replication independently of transcription. The initial observation was the inhibition of the replication of episomal DNA by anti-Myc antibodies [196]. Later on, it was shown that Myc stimulates DNA replication in a transcriptional-independent manner. Myc interacts with the prereplicative complex and localizes to origins of DNA replication in mammalian cells and in Xenopus cell-free extracts. Myc depletion provokes a slow replication due to defective replication initiation once the pre-replicative complexes are assembled [197]. Myc overexpression initiates premature origin firing and increases origin density, and leads to asymmetrical fork progression [197, 198]. Thus, this mechanism explains that, when deregulated, Myc generates DNA replication stress and DNA damage, an observation made in several models [199-202]. Also, high Myc levels enhance re-replication of DNA in the p21induced polyploidization process of myeloid cells [203]. However, it is unclear whether this nontranscriptional Myc activity on replication contributes to the DNA replication in the S-phase of cells with physiological Myc levels. Last but not least, Myc activates the transcription of human telomerase (TERT), which may contribute to sustain the proliferation of tumor cells along the cell cycle [204, 205].

Finally, not only Cdk1 and mitotic cyclins, but some genes encoding proteins required for mitosis are also regulated by Myc. The anaphase promoting complex/cyclosome (APC/C) is a multisubunit E3 ubiquitin ligase required for mitotic progression by targeting for destruction key mitotic regulators such as cyclin B1 and securin, the separase inhibitor required for the correct anaphase $[206,207]$. Myc induce the genes encoding three subunits of APC/C: Anapc5, Cdc16 and Cdc23 [103] and binds their promoter in mouse embryonic stem (ES) cells and human myeloid cells ([107] and ENCODE project, http://genome.ucsc.edu/). Myc would not only promote securin degradation through upregulation of $\mathrm{APC} / \mathrm{C}$ sununits but also repress the securin gene (Pttg1) [103], suggesting a major role in mitotic control. On the other hand, it has also been reported that Myc represses Anapc2 (another component of the APC/C complex) and Cdc20, the APC/C coactivator [103]. Moreover, Myc also activates the expression of human BubR1 and Mad2 genes, two APC/C repressors, delaying prometaphase [208]. The effects of Myc on mitotic progression are not well understood yet, although the Myc-mediated induction of some of these regulators (e.g, BubR1 and Mad2) has been related to the chromosomal instability elicited by deregulated Myc [208-210]

\section{Conclusion and remarks}


We have reviewed here the many functions of Myc related to the cell cycle regulation. From the pioneering studies in the 1980's to the genome-wide studies today, the general picture shows that control of cell proliferation is one of the major roles of Myc in cell biology. The bulk of data shows that Myc overexpression stimulates whereas Myc downregulation inhibits cell cycle progression. Several mechanisms by which Myc influences the cell cycle have been elucidated. Most of them are related to the Myc-mediated induction or repression of target genes encoding positive or negative cell cycle regulators, respectively. However, there are still many unclear aspects of these mechanisms. The stimulation of cell cycle progression is likely the most relevant activity -albeit not the only one - for the oncogenic activity of Myc. Given the frequent deregulation of Myc oncogene observed in many human tumours it is of crucial importance to further decipher the molecular mechanisms underlying the role of Myc on the regulation of the cell cycle. Although Myc is not an easily druggable target, a promising approach to deal with tumors with deregulated Myc is the synthetic lethality based on the inhibition of Cdks. In this line, it has been described synthetic-lethal interaction between Myc and Cdk1 in lymphoma, liver cancer and breast cancer [211, 212]. The effort to elucidate the Myc-dependent cell cycle regulatory mechanisms would eventually help to discover new therapeutic approaches directed against malignancies with deregulated Myc.

\section{Acknowledgments}

The work in the laboratory of the authors is funded by grants SAF11-23796 from Spanish Ministry of Industry and Innovation, and ISCIII-RETIC RD12/0036/0033 from Spanish Ministry of Health to JL, and FIS 11/00397 to MDD. GB is recipient of a fellowship form the FPI Program. We apologize to colleagues whose work has not been cited in the form of their original papers but in reviews and whose work has not been discussed due to space limitations or unintentional omission.

\section{References}

[1] M. Malumbres, M. Barbacid. Mammalian cyclin-dependent kinases Trends Biochem Sci, 30 (2005), pp. 630-641.

[2] M. Malumbres, E. Harlow, T. Hunt, T. Hunter, J.M. Lahti, G. Manning, D.O. Morgan, L.H. Tsai, D.J. Wolgemuth. Cyclin-dependent kinases: a family portrait Nat Cell Biol, 11 (2009), pp. 1275-1276.

[3] A. Deshpande, P. Sicinski, P.W. Hinds. Cyclins and cdks in development and cancer: a perspective Oncogene, 24 (2005), pp. 2909-2915.

[4] I. Sanchez, B.D. Dynlacht. New insights into cyclins, CDKs, and cell cycle control Semin Cell Dev Biol, 16 (2005), pp. 311-321.

[5] C.J. Sherr. D-type cyclins Trends Biochem Sci, 20 (1995), pp. 187-190.

[6] N. Dyson. The regulation of E2F by pRB-family proteins Genes Dev, 12 (1998), pp. 22452262.

[7] J.R. Nevins. The Rb/E2F pathway and cancer Hum Mol Genet, 10 (2001), pp. 699-703.

[8] C. Sweeney, M. Murphy, M. Kubelka, S.E. Ravnik, C.F. Hawkins, D.J. Wolgemuth, M. Carrington. A distinct cyclin A is expressed in germ cells in the mouse Development, 122 (1996), pp. 53-64.

[9] R. Yang, R. Morosetti, H.P. Koeffler. Characterization of a second human cyclin A that is highly expressed in testis and in several leukemic cell lines Cancer Res, 57 (1997), pp. 913920.

[10] F. Girard, U. Strausfeld, A. Fernandez, N.J. Lamb. Cyclin A is required for the onset of DNA replication in mammalian fibroblasts Cell, 67 (1991), pp. 1169-1179. 
[11] S. Geley, E. Kramer, C. Gieffers, J. Gannon, J.M. Peters, T. Hunt. Anaphase-promoting complex/cyclosome-dependent proteolysis of human cyclin A starts at the beginning of mitosis and is not subject to the spindle assembly checkpoint J Cell Biol, 153 (2001), pp. 137-148.

[12] C.J. Sherr, J.M. Roberts. Living with or without cyclins and cyclin-dependent kinases Genes Dev, 18 (2004), pp. 2699-2711.

[13] J.C. Lozano, E. Perret, P. Schatt, C. Arnould, G. Peaucellier, A. Picard. Molecular cloning, gene localization, and structure of human cyclin B3 Biochem Biophys Res Commun, 291 (2002), pp. 406-413.

[14] T.B. Nguyen, K. Manova, P. Capodieci, C. Lindon, S. Bottega, X.Y. Wang, J. Refik-Rogers, J. Pines, D.J. Wolgemuth, A. Koff. Characterization and expression of mammalian cyclin b3, a prepachytene meiotic cyclin J Biol Chem, 277 (2002), pp. 41960-41969.

[15] J.W. Harper, J.L. Burton, M.J. Solomon. The anaphase-promoting complex: it's not just for mitosis any more Genes Dev, 16 (2002), pp. 2179-2206.

[16] S. Ortega, I. Prieto, J. Odajima, A. Martin, P. Dubus, R. Sotillo, J.L. Barbero, M. Malumbres, $M$. Barbacid. Cyclin-dependent kinase 2 is essential for meiosis but not for mitotic cell division in mice Nat Genet, 35 (2003), pp. 25-31.

[17] C. Berthet, E. Aleem, V. Coppola, L. Tessarollo, P. Kaldis. Cdk2 knockout mice are viable Curr Biol, 13 (2003), pp. 1775-1785.

[18] S.G. Rane, P. Dubus, R.V. Mettus, E.J. Galbreath, G. Boden, E.P. Reddy, M. Barbacid. Loss of Cdk4 expression causes insulin-deficient diabetes and Cdk4 activation results in betaislet cell hyperplasia Nat Genet, 22 (1999), pp. 44-52.

[19] T. Tsutsui, B. Hesabi, D.S. Moons, P.P. Pandolfi, K.S. Hansel, A. Koff, H. Kiyokawa. Targeted disruption of CDK4 delays cell cycle entry with enhanced p27(Kip1) activity Mol Cell Biol, 19 (1999), pp. 7011-7019.

[20] M. Malumbres, R. Sotillo, D. Santamaria, J. Galan, A. Cerezo, S. Ortega, P. Dubus, M. Barbacid. Mammalian cells cycle without the D-type cyclin-dependent kinases Cdk4 and Cdk6 Cell, 118 (2004), pp. 493-504.

[21] D. Santamaria, C. Barriere, A. Cerqueira, S. Hunt, C. Tardy, K. Newton, J.F. Caceres, P. Dubus, M. Malumbres, M. Barbacid. Cdk1 is sufficient to drive the mammalian cell cycle Nature, 448 (2007), pp. 811-815.

[22] K. Kozar, M.A. Ciemerych, V.I. Rebel, H. Shigematsu, A. Zagozdzon, E. Sicinska, Y. Geng, Q. Yu, S. Bhattacharya, R.T. Bronson, K. Akashi, P. Sicinski. Mouse development and cell proliferation in the absence of D-cyclins Cell, 118 (2004), pp. 477-491.

[23] Y. Geng, Q. Yu, E. Sicinska, M. Das, J.E. Schneider, S. Bhattacharya, W.M. Rideout, R.T. Bronson, H. Gardner, P. Sicinski. Cyclin E ablation in the mouse Cell, 114 (2003), pp. 431443.

[24] T. Parisi, A.R. Beck, N. Rougier, T. McNeil, L. Lucian, Z. Werb, B. Amati. Cyclins E1 and E2 are required for endoreplication in placental trophoblast giant cells Embo J, 22 (2003), pp. 4794-4803.

[25] I. Kalaszczynska, Y. Geng, T. lino, S. Mizuno, Y. Choi, I. Kondratiuk, D.P. Silver, D.J. Wolgemuth, K. Akashi, P. Sicinski. Cyclin A is redundant in fibroblasts but essential in hematopoietic and embryonic stem cells Cell, 138 (2009), pp. 352-365.

[26] M. Brandeis, I. Rosewell, M. Carrington, T. Crompton, M.A. Jacobs, J. Kirk, J. Gannon, T. Hunt. Cyclin B2-null mice develop normally and are fertile whereas cyclin B1-null mice die in utero Proc Natl Acad Sci U S A, 95 (1998), pp. 4344-4349.

[27] H. Hochegger, S. Takeda, T. Hunt. Cyclin-dependent kinases and cell-cycle transitions: does one fit all? Nat Rev Mol Cell Biol, 9 (2008), pp. 910-916.

[28] M. Murphy, M.G. Stinnakre, C. Senamaud-Beaufort, N.J. Winston, C. Sweeney, M. Kubelka, M. Carrington, C. Brechot, J. Sobczak-Thepot. Delayed early embryonic lethality following disruption of the murine cyclin A2 gene Nat Genet, 15 (1997), pp. 83-86.

[29] C.J. Sherr, J.M. Roberts. CDK inhibitors: positive and negative regulators of G1-phase progression Genes Dev, 13 (1999), pp. 1501-1512.

[30] N.P. Pavletich. Mechanisms of cyclin-dependent kinase regulation: structures of Cdks, their cyclin activators, and Cip and INK4 inhibitors J Mol Biol, 287 (1999), pp. 821-828.

[31] M. Eilers, R.N. Eisenman. Myc's broad reach Genes Dev, 22 (2008), pp. 2755-2766.

[32] N. Meyer, L.Z. Penn. Reflecting on 25 years with MYC Nat Rev Cancer, 8 (2008), pp. 976990.

[33] C.V. Dang. MYC on the path to cancer Cell, 149 (2012), pp. 22-35.

[34] B. Luscher, J. Vervoorts. Regulation of gene transcription by the oncoprotein MYC Gene, 494 (2012), pp. 145-160. 
[35] C.E. Nesbit, J.M. Tersak, E.V. Prochownik. MYC oncogenes and human neoplastic disease Oncogene, 18 (1999), pp. 3004-3016.

[36] M. Vita, M. Henriksson. The Myc oncoprotein as a therapeutic target for human cancer Semin Cancer Biol, 16 (2006), pp. 318-330.

[37] M.D. Delgado, J. Leon. Myc roles in hematopoiesis and leukemia Genes Cancer, 1 (2010), pp. 605-616.

[38] K. Kelly, B.H. Cochran, C.D. Stiles, P. Leder. Cell-specific regulation of the c-myc gene by lymphocyte mitogens and platelet-derived growth factor Cell, 35 (1983), pp. 603-610.

[39] M. Dean, R.A. Levine, W. Ran, M.S. Kindy, G.E. Sonenshein, J. Campisi. Regulation of cmyc transcription and mRNA abundance by serum growth factors and cell contact $\mathrm{J}$ Biol Chem, 261 (1986), pp. 9161-9166.

[40] J.C. Reed, J.D. Alpers, P.C. Nowell, R.G. Hoover. Sequential expression of protooncogenes during lectin-stimulated mitogenesis of normal human lymphocytes Proc Natl Acad Sci U S A, 83 (1986), pp. 3982-3986.

[41] C.M. Waters, T.D. Littlewood, D.C. Hancock, J.P. Moore, G.I. Evan. c-myc protein expression in untransformed fibroblasts Oncogene, 6 (1991), pp. 797-805.

[42] C.B. Thompson, P.B. Challoner, P.E. Neiman, M. Groudine. Levels of c-myc oncogene mRNA are invariant throughout the cell cycle Nature, 314 (1985), pp. 363-366.

[43] P.H. Rabbitts, J.V. Watson, A. Lamond, A. Forster, M.A. Stinson, G. Evan, W. Fischer, E. Atherton, R. Sheppard, T.H. Rabbitts. Metabolism of c-myc gene products: c-myc mRNA and protein expression in the cell cycle EMBO J, 4 (1985), pp. 2009-2015.

[44] E. Kerkhoff, R. Houben, S. Loffler, J. Troppmair, J.E. Lee, U.R. Rapp. Regulation of c-myc expression by Ras/Raf signalling Oncogene, 16 (1998), pp. 211-216.

[45] M.F. Roussel, J.N. Davis, J.L. Cleveland, J. Ghysdael, S.W. Hiebert. Dual control of myc expression through a single DNA binding site targeted by ets family proteins and E2F-1 Oncogene, 9 (1994), pp. 405-415.

[46] I. Grigorieva, V.G. Grigoriev, M.K. Rowney, R.G. Hoover. Regulation of c-myc transcription by interleukin-2 (IL-2). Identification of a novel IL-2 response element interacting with STAT-4 J Biol Chem, 275 (2000), pp. 7343-7350.

[47] W.H. Lee, F.H. Liu, J.Y. Lin, S.Y. Huang, H. Lin, W.J. Liao, H.M. Huang. JAK pathway induction of c-Myc critical to IL-5 stimulation of cell proliferation and inhibition of apoptosis $\mathrm{J}$ Cell Biochem, 106 (2009), pp. 929-936.

[48] M.A. Dominguez-Caceres, J.M. Garcia-Martinez, A. Calcabrini, L. Gonzalez, P.G. Porque, J. Leon, J. Martin-Perez. Prolactin induces c-Myc expression and cell survival through activation of Src/Akt pathway in lymphoid cells Oncogene, 23 (2004), pp. 7378-7390.

[49] S. Xie, H. Lin, T. Sun, R.B. Arlinghaus. Jak2 is involved in c-Myc induction by Bcr-Abl Oncogene, 21 (2002), pp. 7137-7146.

[50] M.T. Gomez-Casares, E. Garcia-Alegria, C.E. Lopez-Jorge, N. Ferrandiz, R. Blanco, S. Alvarez, J.P. Vaque, G. Bretones, J.M. Caraballo, P. Sanchez-Bailon, M.D. Delgado, J. MartinPerez, J.C. Cigudosa, J. Leon. MYC antagonizes the differentiation induced by imatinib in chronic myeloid leukemia cells through downregulation of p27(KIP1.) Oncogene, 32 (2013), pp. 2239-2246.

[51] T. Skorski, A. Bellacosa, M. Nieborowska-Skorska, M. Majewski, R. Martinez, J.K. Choi, R. Trotta, P. Wlodarski, D. Perrotti, T.O. Chan, M.A. Wasik, P.N. Tsichlis, B. Calabretta. Transformation of hematopoietic cells by BCR/ABL requires activation of a PI-3k/Akt-dependent pathway EMBO J, 16 (1997), pp. 6151-6161.

[52] A.K. Samanta, H. Lin, T. Sun, H. Kantarjian, R.B. Arlinghaus. Janus kinase 2: a critical target in chronic myelogenous leukemia Cancer Res, 66 (2006), pp. 6468-6472.

[53] J.A. Pietenpol, J.T. Holt, R.W. Stein, H.L. Moses. Transforming growth factor beta 1 suppression of c-myc gene transcription: role in inhibition of keratinocyte proliferation Proc Natl Acad Sci U S A, 87 (1990), pp. 3758-3762.

[54] M.G. Alexandrow, M. Kawabata, M. Aakre, H.L. Moses. Overexpression of the c-Myc oncoprotein blocks the growth-inhibitory response but is required for the mitogenic effects of transforming growth factor beta 1 Proc Natl Acad Sci U S A, 92 (1995), pp. 3239-3243.

[55] A. Malliri, W.A. Yeudall, M. Nikolic, D.H. Crouch, E.K. Parkinson, B. Ozanne. Sensitivity to transforming growth factor beta 1-induced growth arrest is common in human squamous cell carcinoma cell lines: c-MYC down-regulation and p21waf1 induction are important early events Cell Growth Differ, 7 (1996), pp. 1291-1304. 
[56] C.V. Ramana, N. Grammatikakis, M. Chernov, H. Nguyen, K.C. Goh, B.R. Williams, G.R. Stark. Regulation of c-myc expression by IFN-gamma through Stat1-dependent and independent pathways EMBO J, 19 (2000), pp. 263-272.

[57] C.R. Chen, Y. Kang, P.M. Siegel, J. Massague. E2F4/5 and p107 as Smad cofactors linking the TGFbeta receptor to c-myc repression Cell, 110 (2002), pp. 19-32.

[58] K. Yagi, M. Furuhashi, H. Aoki, D. Goto, H. Kuwano, K. Sugamura, K. Miyazono, M. Kato. c-myc is a downstream target of the Smad pathway J Biol Chem, 277 (2002), pp. 854-861.

[59] J.A. Coppola, M.D. Cole. Constitutive c-myc oncogene expression blocks mouse erythroleukaemia cell differentiation but not commitment Nature, 320 (1986), pp. 760-763.

[60] E.V. Prochownik, J. Kukowska. Deregulated expression of c-myc by murine erythroleukaemia cells prevents differentiation Nature, 322 (1986), pp. 848-850.

[61] E. Dmitrovsky, W.M. Kuehl, G.F. Hollis, I.R. Kirsch, T.P. Bender, S. Segal. Expression of a transfected human c-myc oncogene inhibits differentiation of a mouse erythroleukaemia cell line Nature, 322 (1986), pp. 748-750.

[62] J. Leon, N. Ferrandiz, J.C. Acosta, M.D. Delgado. Inhibition of cell differentiation: A critical mechanism for MYC-mediated carcinogenesis? Cell Cycle, 8 (2009), pp. 1148-1157.

[63] H.A. Armelin, M.C. Armelin, K. Kelly, T. Stewart, P. Leder, B.H. Cochran, C.D. Stiles. Functional role for c-myc in mitogenic response to platelet-derived growth factor Nature, 310 (1984), pp. 655-660.

[64] L. Kaczmarek, J.K. Hyland, R. Watt, M. Rosenberg, R. Baserga. Microinjected c-myc as a competence factor Science, 228 (1985), pp. 1313-1315.

[65] V. Sorrentino, V. Drozdoff, M.D. McKinney, L. Zeitz, E. Fleissner. Potentiation of growth factor activity by exogenous c-myc expression Proc Natl Acad Sci U S A, 83 (1986), pp. 8167 8171.

[66] J. Karn, J.V. Watson, A.D. Lowe, S.M. Green, W. Vedeckis. Regulation of cell cycle duration by c-myc levels Oncogene, 4 (1989), pp. 773-787.

[67] B.M. Iritani, R.N. Eisenman. C-Myc enhances protein synthesis and cell size during B lymphocyte development Proc Natl Acad Sci U S A, 96 (1999), pp. 13180-13185.

[68] L.A. Johnston, D.A. Prober, B.A. Edgar, R.N. Eisenman, P. Gallant. Drosophila myc regulates cellular growth during development Cell, 98 (1999), pp. 779-790.

[69] M.E. Piedra, M.D. Delgado, M.A. Ros, J. Leon. c-Myc Overexpression Increases Cell Size and Impairs Cartilage Differentiation during Chick Limb Development Cell Growth Differ, 13 (2002), pp. 185-193.

[70] M. Eilers, S. Schirm, J.M. Bishop. The MYC protein activates transcription of the alphaprothymosin gene Embo J, 10 (1991), pp. 133-141.

[71] M. Schuhmacher, M.S. Staege, A. Pajic, A. Polack, U.H. Weidle, G.W. Bornkamm, D. Eick, F. Kohlhuber. Control of cell growth by c-Myc in the absence of cell division Curr Biol, 9 (1999), pp. 1255-1258.

[72] M. Schuhmacher, D. Eick. Dose-dependent regulation of target gene expression and cell proliferation by c-Myc levels Transcription, 4 (2013), pp.

[73] I. Schlosser, M. Holzel, R. Hoffmann, H. Burtscher, F. Kohlhuber, M. Schuhmacher, R. Chapman, U.H. Weidle, D. Eick. Dissection of transcriptional programmes in response to serum and C-Myc in a human B-cell line Oncogene, 24 (2005), pp. 520-524.

[74] R. Heikkila, G. Schwab, E. Wickstrom, S.L. Loke, D.H. Pluznik, R. Watt, L.M. Neckers. A cmyc antisense oligodeoxynucleotide inhibits entry into $S$ phase but not progress from $G 0$ to $G 1$ Nature, 328 (1987), pp. 445-449.

[75] E.L. Wickstrom, T.A. Bacon, A. Gonzalez, D.L. Freeman, G.H. Lyman, E. Wickstrom. Human promyelocytic leukemia HL-60 cell proliferation and c-myc protein expression are inhibited by an antisense pentadecadeoxynucleotide targeted against c-myc mRNA Proc Natl Acad Sci U S A, 85 (1988), pp. 1028-1032.

[76] S. Goruppi, S. Gustincich, C. Brancolini, W.M. Lee, C. Schneider. Dissection of c-myc domains involved in S phase induction of NIH3T3 fibroblasts Oncogene, 9 (1994), pp. 15371544.

[77] H. Hermeking, D.A. Wolf, F. Kohlhuber, A. Dickmanns, M. Billaud, E. Fanning, D. Eick. Role of c-myc in simian virus 40 large tumor antigen-induced DNA synthesis in quiescent 3T3-L1 mouse fibroblasts Proc Natl Acad Sci U S A, 91 (1994), pp. 10412-10416.

[78] E.V. Prochownik, J. Kukowska, C. Rodgers. c-myc antisense transcripts accelerate differentiation and inhibit $\mathrm{G} 1$ progression in murine erythroleukemia cells Mol Cell Biol, 8 (1988), pp. 3683-3695. 
[79] H. Wang, S. Mannava, V. Grachtchouk, D. Zhuang, M.S. Soengas, A.V. Gudkov, E.V. Prochownik, M.A. Nikiforov. c-Myc depletion inhibits proliferation of human tumor cells at various stages of the cell cycle Oncogene, 27 (2008), pp. 1905-1915.

[80] T.A. Baudino, J.L. Cleveland. The Max network gone mad Mol Cell Biol, 21 (2001), pp. 691-702.

[81] P.J. Hurlin, J. Huang. The MAX-interacting transcription factor network Semin Cancer Biol, 16 (2006), pp. 265-274.

[82] S. Rottmann, B. Luscher. The Mad side of the Max network: antagonizing the function of Myc and more Curr Top Microbiol Immunol, 302 (2006), pp. 63-122.

[83] K. Berns, E.M. Hijmans, R. Bernards. Repression of c-Myc responsive genes in cycling cells causes G1 arrest through reduction of cyclin E/CDK2 kinase activity Oncogene, 15 (1997), pp. 1347-1356.

[84] C. Cerni, B. Skrzypek, N. Popov, S. Sasgary, G. Schmidt, L.G. Larsson, B. Luscher, M. Henriksson. Repression of in vivo growth of Myc/Ras transformed tumor cells by Mad1 Oncogene, 21 (2002), pp. 447-459.

[85] A. Menssen, H. Hermeking. Characterization of the c-MYC-regulated transcriptome by SAGE: identification and analysis of c-MYC target genes Proc Natl Acad Sci U S A, 99 (2002), pp. 6274-6279.

[86] N.C. Dubois, C. Adolphe, A. Ehninger, R.A. Wang, E.J. Robertson, A. Trumpp. Placental rescue reveals a sole requirement for c-Myc in embryonic erythroblast survival and hematopoietic stem cell function Development, 135 (2008), pp. 2455-2465.

[87] M.K. Mateyak, A.J. Obaya, S. Adachi, J.M. Sedivy. Phenotypes of c-Myc-deficient rat fibroblasts isolated by targeted homologous recombination Cell Growth Differ, 8 (1997), pp. 1039-1048.

[88] A. Bush, M. Mateyak, K. Dugan, A. Obaya, S. Adachi, J. Sedivy, M. Cole. c-myc null cells misregulate cad and gadd45 but not other proposed c- Myc targets Genes Dev, 12 (1998), pp. 3797-3802.

[89] M.K. Mateyak, A.J. Obaya, J.M. Sedivy. c-Myc regulates cyclin D-Cdk4 and -Cdk6 activity but affects cell cycle progression at multiple independent points Mol Cell Biol, 19 (1999), pp. 4672-4683.

[90] C. Schorl, J.M. Sedivy. Loss of protooncogene c-Myc function impedes G1 phase progression both before and after the restriction point Mol Biol Cell, 14 (2003), pp. 823-835.

[91] I.M. de Alboran, R.C. O'Hagan, F. Gartner, B. Malynn, L. Davidson, R. Rickert, K. Rajewsky, R.A. DePinho, F.W. Alt. Analysis of C-MYC function in normal cells via conditional gene-targeted mutation Immunity, 14 (2001), pp. 45-55.

[92] K. Berns, E.M. Hijmans, E. Koh, G.Q. Daley, R. Bernards. A genetic screen to identify genes that rescue the slow growth phenotype of c-myc null fibroblasts Oncogene, 19 (2000), pp. 3330-3334.

[93] B. Amati, K. Alevizopoulos, J. Vlach. Myc and the cell cycle Front Biosci, 3 (1998), pp. D250-268.

[94] W. Lutz, J. Leon, M. Eilers. Contributions of Myc to tumorigenesis Biochim Biophys Acta, 1602 (2002), pp. 61-71.

[95] Z. Nie, G. Hu, G. Wei, K. Cui, A. Yamane, W. Resch, R. Wang, D.R. Green, L. Tessarollo, R. Casellas, K. Zhao, D. Levens. C-Myc is a universal amplifier of expressed genes in lymphocytes and embryonic stem cells Cell, 151 (2012), pp. 68-79.

[96] C.Y. Lin, J. Loven, P.B. Rahl, R.M. Paranal, C.B. Burge, J.E. Bradner, T.I. Lee, R.A. Young. Transcriptional amplification in tumor cells with elevated c-Myc Cell, 151 (2012), pp. 56-67.

[97] C.V. Dang. c-Myc target genes involved in cell growth, apoptosis, and metabolism Mol Cell Biol, 19 (1999), pp. 1-11.

[98] M. Schuhmacher, F. Kohlhuber, M. Holzel, C. Kaiser, H. Burtscher, M. Jarsch, G.W. Bornkamm, G. Laux, A. Polack, U.H. Weidle, D. Eick. The transcriptional program of a human B cell line in response to Myc Nucleic Acids Res, 29 (2001), pp. 397-406.

[99] H.A. Coller, C. Grandori, P. Tamayo, T. Colbert, E.S. Lander, R.N. Eisenman, T.R. Golub. Expression analysis with oligonucleotide microarrays reveals that MYC regulates genes involved in growth, cell cycle, signaling, and adhesion Proc Natl Acad Sci U S A, 97 (2000), pp. 3260-3265.

[100] K.I. Zeller, A.G. Jegga, B.J. Aronow, K.A. O'Donnell, C.V. Dang. An integrated database of genes responsive to the Myc oncogenic transcription factor: identification of direct genomic targets Genome Biol, 4 (2003), pp. R69. 
[101] K.I. Zeller, X. Zhao, C.W. Lee, K.P. Chiu, F. Yao, J.T. Yustein, H.S. Ooi, Y.L. Orlov, A. Shahab, H.C. Yong, Y. Fu, Z. Weng, V.A. Kuznetsov, W.K. Sung, Y. Ruan, C.V. Dang, C.L. Wei. Global mapping of c-Myc binding sites and target gene networks in human $B$ cells Proc Natl Acad Sci U S A, 103 (2006), pp. 17834-11749.

[102] I. Schlosser, M. Holzel, M. Murnseer, H. Burtscher, U.H. Weidle, D. Eick. A role for c-Myc in the regulation of ribosomal RNA processing Nucleic Acids Res, 31 (2003), pp. 6148-6156.

[103] C.S. Yap, A.L. Peterson, G. Castellani, J.M. Sedivy, N. Neretti. Kinetic profiling of the cMyc transcriptome and bioinformatic analysis of repressed gene promoters Cell Cycle, 10 (2011), pp. 2184-2196.

[104] D. Perna, G. Faga, A. Verrecchia, M.M. Gorski, I. Barozzi, V. Narang, J. Khng, K.C. Lim, W.K. Sung, R. Sanges, E. Stupka, T. Oskarsson, A. Trumpp, C.L. Wei, H. Muller, B. Amati. Genome-wide mapping of Myc binding and gene regulation in serum-stimulated fibroblasts Oncogene, 31 (2012), pp. 1695-1709.

[105] P.C. Fernandez, S.R. Frank, L. Wang, M. Schroeder, S. Liu, J. Greene, A. Cocito, B. Amati. Genomic targets of the human c-Myc protein Genes Dev, 17 (2003), pp. 1115-1129.

[106] B.L. Kidder, J. Yang, S. Palmer. Stat3 and c-Myc genome-wide promoter occupancy in embryonic stem cells PLoS ONE, 3 (2008), pp. e3932.

[107] J. Kim, A.J. Woo, J. Chu, J.W. Snow, Y. Fujiwara, C.G. Kim, A.B. Cantor, S.H. Orkin. A Myc network accounts for similarities between embryonic stem and cancer cell transcription programs Cell, 143 (2010), pp. 313-324.

[108] Z. Li, S. Van Calcar, C. Qu, W.K. Cavenee, M.Q. Zhang, B. Ren. A global transcriptional regulatory role for c-Myc in Burkitt's lymphoma cells Proc Natl Acad Sci U S A, 100 (2003), pp. 8164-8169.

[109] A. Orian, B. van Steensel, J. Delrow, H.J. Bussemaker, L. Li, T. Sawado, E. Williams, L.W. Loo, S.M. Cowley, C. Yost, S. Pierce, B.A. Edgar, S.M. Parkhurst, R.N. Eisenman. Genomic binding by the Drosophila Myc, Max, Mad/Mnt transcription factor network Genes Dev, 17 (2003), pp. 1101-1114.

[110] E. Guccione, F. Martinato, G. Finocchiaro, L. Luzi, L. Tizzoni, V. Dall' Olio, G. Zardo, C. Nervi, L. Bernard, B. Amati. Myc-binding-site recognition in the human genome is determined by chromatin context Nat Cell Biol, 8 (2006), pp. 764-770.

[111] V. Seitz, P. Butzhammer, B. Hirsch, J. Hecht, I. Gutgemann, A. Ehlers, D. Lenze, E. Oker, A. Sommerfeld, E. von der Wall, C. Konig, C. Zinser, R. Spang, M. Hummel. Deep sequencing of MYC DNA-binding sites in Burkitt lymphoma PLoS One, 6 (2011), pp. e26837.

[112] E.V. Schmidt. The role of c-myc in cellular growth control Oncogene, 18 (1999), pp. 2988-2996.

[113] J. van Riggelen, A. Yetil, D.W. Felsher. MYC as a regulator of ribosome biogenesis and protein synthesis Nat Rev Cancer, 10 (2010), pp. 301-309.

[114] Y.C. Liu, F. Li, J. Handler, C.R. Huang, Y. Xiang, N. Neretti, J.M. Sedivy, K.I. Zeller, C.V. Dang. Global regulation of nucleotide biosynthetic genes by c-Myc PLoS One, 3 (2008), pp. e2722.

[115] C.V. Dang, A. Le, P. Gao. MYC-induced cancer cell energy metabolism and therapeutic opportunities Clin Cancer Res, 15 (2009), pp. 6479-6483.

[116] J.V. Wong, P. Dong, J.R. Nevins, B. Mathey-Prevot, L. You. Network calisthenics: control of E2F dynamics in cell cycle entry Cell Cycle, 10 (2011), pp. 3086-3094.

[117] G. Leone, R. Sears, E. Huang, R. Rempel, F. Nuckolls, C.H. Park, P. Giangrande, L. Wu, H.I. Saavedra, S.J. Field, M.A. Thompson, H. Yang, Y. Fujiwara, M.E. Greenberg, S. Orkin, C. Smith, J.R. Nevins. Myc requires distinct E2F activities to induce $S$ phase and apoptosis Mol Cell, 8 (2001), pp. 105-113.

[118] M.R. Adams, R. Sears, F. Nuckolls, G. Leone, J.R. Nevins. Complex transcriptional regulatory mechanisms control expression of the E2F3 locus Mol Cell Biol, 20 (2000), pp. 3633-3639.

[119] R. Sears, K. Ohtani, J.R. Nevins. Identification of positively and negatively acting elements regulating expression of the E2F2 gene in response to cell growth signals Mol Cell Biol, 17 (1997), pp. 5227-5235.

[120] R.J. Rounbehler, P.M. Rogers, C.J. Conti, D.G. Johnson. Inactivation of E2f1 enhances tumorigenesis in a Myc transgenic model Cancer Res, 62 (2002), pp. 3276-3281.

[121] K.A. O'Donnell, E.A. Wentzel, K.I. Zeller, C.V. Dang, J.T. Mendell. c-Myc-regulated microRNAs modulate E2F1 expression Nature, 435 (2005), pp. 839-843. 
[122] Y. Sylvestre, V. De Guire, E. Querido, U.K. Mukhopadhyay, V. Bourdeau, F. Major, G. Ferbeyre, P. Chartrand. An E2F/miR-20a autoregulatory feedback loop J Biol Chem, 282 (2007), pp. 2135-2143.

[123] K. Thalmeier, H. Synovzik, R. Mertz, E.L. Winnacker, M. Lipp. Nuclear factor E2F mediates basic transcription and trans-activation by E1a of the human MYC promoter Genes Dev, 3 (1989), pp. 527-536.

[124] F. Oswald, H. Lovec, T. Moroy, M. Lipp. E2F-dependent regulation of human MYC: transactivation by cyclins D1 and A overrides tumour suppressor protein functions Oncogene, 9 (1994), pp. 2029-2036.

[125] J. Alvaro-Blanco, L. Martinez-Gac, E. Calonge, M. Rodriguez-Martinez, I. Molina-Privado, J.M. Redondo, J. Alcami, E.K. Flemington, M.R. Campanero. A novel factor distinct from E2F mediates C-MYC promoter activation through its E2F element during exit from quiescence Carcinogenesis, 30 (2009), pp. 440-448.

[126] T.C. Chang, D. Yu, Y.S. Lee, E.A. Wentzel, D.E. Arking, K.M. West, C.V. Dang, A. Thomas-Tikhonenko, J.T. Mendell. Widespread microRNA repression by Myc contributes to tumorigenesis Nat Genet, 40 (2008), pp. 43-50.

[127] M.J. Bueno, M. Malumbres. MicroRNAs and the cell cycle Biochim Biophys Acta, 1812 (2011), pp. 592-601.

[128] C.D. Johnson, A. Esquela-Kerscher, G. Stefani, M. Byrom, K. Kelnar, D. Ovcharenko, M. Wilson, X. Wang, J. Shelton, J. Shingara, L. Chin, D. Brown, F.J. Slack. The let-7 microRNA represses cell proliferation pathways in human cells Cancer Res, 67 (2007), pp. 7713-7722.

[129] T.V. Bui, J.T. Mendell. Myc: Maestro of MicroRNAs Genes Cancer, 1 (2010), pp. 568575.

[130] P. Steiner, A. Philipp, J. Lukas, D. Godden-Kent, M. Pagano, S. Mittnacht, J. Bartek, M. Eilers. Identification of a Myc-dependent step during the formation of active G1 cyclin-cdk complexes Embo J, 14 (1995), pp. 4814-4826.

[131] I. Perez-Roger, D.L. Solomon, A. Sewing, H. Land. Myc activation of cyclin E/Cdk2 kinase involves induction of cyclin E gene transcription and inhibition of p27(Kip1) binding to newly formed complexes Oncogene, 14 (1997), pp. 2373-2381.

[132] O. Pusch, G. Bernaschek, M. Eilers, M. Hengstschlager. Activation of c-Myc uncouples DNA replication from activation of G1-cyclin-dependent kinases Oncogene, 15 (1997), pp. 649-656.

[133] H. Hermeking, C. Rago, M. Schuhmacher, Q. Li, J.F. Barrett, A.J. Obaya, B.C. O'Connell, M.K. Mateyak, W. Tam, F. Kohlhuber, C.V. Dang, J.M. Sedivy, D. Eick, B. Vogelstein, K.W. Kinzler. Identification of CDK4 as a target of c-MYC Proc Natl Acad Sci U S A, 97 (2000), pp. 2229-2234.

[134] J. Kim, J.H. Lee, V.R. Iyer. Global identification of Myc target genes reveals its direct role in mitochondrial biogenesis and its E-box usage in vivo PLoS ONE, 3 (2008), pp. e1798.

[135] Y. Qi, Y. Tu, D. Yang, Q. Chen, J. Xiao, Y. Chen, J. Fu, X. Xiao, Z. Zhou. Cyclin A but not cyclin D1 is essential for c-myc-modulated cell-cycle progression J Cell Physiol, 210 (2007), pp. 63-71.

[136] K.D. Hanson, M. Shichiri, M.R. Follansbee, J.M. Sedivy. Effects of c-myc expression on cell cycle progression Mol Cell Biol, 14 (1994), pp. 5748-5755.

[137] Z.J. Liu, T. Ueda, T. Miyazaki, N. Tanaka, S. Mine, Y. Tanaka, T. Taniguchi, H. Yamamura, Y. Minami. A critical role for cyclin $\mathrm{C}$ in promotion of the hematopoietic cell cycle by cooperation with c-Myc Mol Cell Biol, 18 (1998), pp. 3445-3454.

[138] T.L. Born, J.A. Frost, A. Schonthal, G.C. Prendergast, J.R. Feramisco. c-Myc cooperates with activated Ras to induce the cdc2 promoter Mol Cell Biol, 14 (1994), pp. 5710-5718.

[139] I. Perez-Roger, S.H. Kim, B. Griffiths, A. Sewing, H. Land. Cyclins D1 and D2 mediate myc-induced proliferation via sequestration of p27(Kip1) and p21(Cip1) EMBO J, 18 (1999), pp. 5310-5320.

[140] Q. Yu, M.A. Ciemerych, P. Sicinski. Ras and Myc can drive oncogenic cell proliferation through individual D-cyclins Oncogene, 24 (2005), pp. 7114-7119.

[141] J.I. Daksis, R.Y. Lu, L.M. Facchini, W.W. Marhin, L.J. Penn. Myc induces cyclin D1 expression in the absence of de novo protein synthesis and links mitogen-stimulated signal transduction to the cell cycle Oncogene, 9 (1994), pp. 3635-3645.

[142] P. Jansen-Durr, A. Meichle, P. Steiner, M. Pagano, K. Finke, J. Botz, J. Wessbecher, G. Draetta, M. Eilers. Differential modulation of cyclin gene expression by MYC Proc Natl Acad Sci U S A, 90 (1993), pp. 3685-3689. 
[143] A. Philipp, A. Schneider, I. Vasrik, K. Finke, Y. Xiong, D. Beach, K. Alitalo, M. Eilers. Repression of cyclin D1: a novel function of MYC Mol Cell Biol, 14 (1994), pp. 4032-4043.

[144] D.L. Solomon, A. Philipp, H. Land, M. Eilers. Expression of cyclin D1 mRNA is not upregulated by Myc in rat fibroblasts Oncogene, 11 (1995), pp. 1893-1897.

[145] C. Bouchard, K. Thieke, A. Maier, R. Saffrich, J. Hanley-Hyde, W. Ansorge, S. Reed, P. Sicinski, J. Bartek, M. Eilers. Direct induction of cyclin D2 by Myc contributes to cell cycle progression and sequestration of p27 EMBO J, 18 (1999), pp. 5321-5333.

[146] C. Bouchard, O. Dittrich, A. Kiermaier, K. Dohmann, A. Menkel, M. Eilers, B. Luscher. Regulation of cyclin D2 gene expression by the Myc/Max/Mad network: Myc-dependent TRRAP recruitment and histone acetylation at the cyclin D2 promoter Genes Dev, 15 (2001), pp. 20422047.

[147] K. Ohtani, J. DeGregori, J.R. Nevins. Regulation of the cyclin E gene by transcription factor E2F1 Proc Natl Acad Sci U S A, 92 (1995), pp. 12146-12150.

[148] J.F. Barrett, B.C. Lewis, A.T. Hoang, R.J. Alvarez, Jr., C.V. Dang. Cyclin A links C-Myc to adhesion-independent cell proliferation J Biol Chem, 270 (1995), pp. 15923-15925.

[149] A.T. Hoang, K.J. Cohen, J.F. Barrett, D.A. Bergstrom, C.V. Dang. Participation of cyclin A in Myc-induced apoptosis Proc Natl Acad Sci U S A, 91 (1994), pp. 6875-6879.

[150] H.R. Seo, J. Kim, S. Bae, J.W. Soh, Y.S. Lee. Cdk5-mediated phosphorylation of c-Myc on Ser-62 is essential in transcriptional activation of cyclin B1 by cyclin G1 J Biol Chem, 283 (2008), pp. 15601-15610.

[151] X.Y. Yin, L. Grove, N.S. Datta, K. Katula, M.W. Long, E.V. Prochownik. Inverse regulation of cyclin B1 by c-Myc and p53 and induction of tetraploidy by cyclin B1 overexpression Cancer Res, 61 (2001), pp. 6487-6493.

[152] D.O. Morgan. Principles of CDK regulation Nature, 374 (1995), pp. 131-134.

[153] D.O. Morgan. Cyclin-dependent kinases: engines, clocks, and microprocessors Annu Rev Cell Dev Biol, 13 (1997), pp. 261-291.

[154] G. Lolli, L.N. Johnson. CAK-Cyclin-dependent Activating Kinase: a key kinase in cell cycle control and a target for drugs? Cell Cycle, 4 (2005), pp. 572-577.

[155] V.H. Cowling, M.D. Cole. The Myc transactivation domain promotes global phosphorylation of the RNA polymerase II carboxy-terminal domain independently of direct DNA binding Mol Cell Biol, 27 (2007), pp. 2059-2073.

[156] A.J. Obaya, I. Kotenko, M.D. Cole, J.M. Sedivy. The proto-oncogene c-myc acts through the cyclin-dependent kinase (Cdk) inhibitor p27(Kip1) to facilitate the activation of Cdk4/6 and early G(1) phase progression J Biol Chem, 277 (2002), pp. 31263-31269.

[157] C. Bouchard, J. Marquardt, A. Bras, R.H. Medema, M. Eilers. Myc-induced proliferation and transformation require Akt-mediated phosphorylation of FoxO proteins Embo J, 23 (2004), pp. 2830-2840.

[158] L.L. Parker, H. Piwnica-Worms. Inactivation of the p34cdc2-cyclin B complex by the human WEE1 tyrosine kinase Science, 257 (1992), pp. 1955-1957.

[159] J.W. Kim, S. Mori, J.R. Nevins. Myc-induced microRNAs integrate Myc-mediated cell proliferation and cell fate Cancer Res, 70 (2010), pp. 4820-4828.

[160] J.H. Schulte, S. Horn, T. Otto, B. Samans, L.C. Heukamp, U.C. Eilers, M. Krause, K. Astrahantseff, L. Klein-Hitpass, R. Buettner, A. Schramm, H. Christiansen, M. Eilers, A. Eggert, B. Berwanger. MYCN regulates oncogenic MicroRNAs in neuroblastoma Int J Cancer, 122 (2008), pp. 699-704.

[161] L. Lupini, C. Bassi, M. Ferracin, N. Bartonicek, L. D'Abundo, B. Zagatti, E. Callegari, G. Musa, F. Moshiri, L. Gramantieri, F.J. Corrales, A.J. Enright, S. Sabbioni, M. Negrini. miR-221 affects multiple cancer pathways by modulating the level of hundreds messenger RNAs Front Genet, 4 (2013), pp. 64.

[162] C. le Sage, R. Nagel, D.A. Egan, M. Schrier, E. Mesman, A. Mangiola, C. Anile, G. Maira, N. Mercatelli, S.A. Ciafre, M.G. Farace, R. Agami. Regulation of the p27(Kip1) tumor suppressor by miR-221 and miR-222 promotes cancer cell proliferation Embo J, 26 (2007), pp. 3699-3708. [163] K. Galaktionov, X. Chen, D. Beach. Cdc25 cell-cycle phosphatase as a target of c-myc Nature, 382 (1996), pp. 511-517.

[164] G.F. Claassen, S.R. Hann. A role for transcriptional repression of p21CIP1 by c-Myc in overcoming transforming growth factor beta -induced cell-cycle arrest Proc Natl Acad Sci U S A, 97 (2000), pp. 9498-9503.

[165] K. Peukert, P. Staller, A. Schneider, G. Carmichael, F. Hanel, M. Eilers. An alternative pathway for gene regulation by Myc Embo J, 16 (1997), pp. 5672-5686. 
[166] T. Moroy, I. Saba, C. Kosan. The role of the transcription factor Miz-1 in lymphocyte development and lymphomagenesis-Binding Myc makes the difference Semin Immunol, 23 (2011), pp. 379-387.

[167] J. Seoane, H.V. Le, J. Massague. Myc suppression of the p21(Cip1) Cdk inhibitor influences the outcome of the p53 response to DNA damage Nature, 419 (2002), pp. 729-734.

[168] S. Wu, C. Cetinkaya, M.J. Munoz-Alonso, N. Von Der Lehr, F. Bahram, V. Beuger, M. Eilers, J. Leon, L.G. Larsson. Myc represses differentiation-induced p21CIP1 expression via Miz-1-dependent interaction with the p21 core promoter Oncogene, 22 (2003), pp. 351-360.

[169] C. Brenner, R. Deplus, C. Didelot, A. Loriot, E. Vire, C. De Smet, A. Gutierrez, D. Danovi, D. Bernard, T. Boon, P.G. Pelicci, B. Amati, T. Kouzarides, Y. de Launoit, L. Di Croce, F. Fuks. Myc represses transcription through recruitment of DNA methyltransferase corepressor EMBO J, 24 (2005), pp. 336-346.

[170] P. Jung, H. Hermeking. The c-MYC-AP4-p21 cascade Cell Cycle, 8 (2009), pp. 982-989.

[171] J.P. Vaque, J. Navascues, Y. Shiio, M. Laiho, N. Ajenjo, I. Mauleon, D. Matallanas, P. Crespo, J. Leon. Myc antagonizes Ras-mediated growth arrest in leukemia cells through the inhibition of the Ras-ERK-p21Cip1 pathway J Biol Chem, 280 (2005), pp. 1112-1122.

[172] A.L. Gartel, X. Ye, E. Goufman, P. Shianov, N. Hay, F. Najmabadi, A.L. Tyner. Myc represses the p21(WAF1/CIP1) promoter and interacts with Sp1/Sp3 Proc Natl Acad Sci U S A, 98 (2001), pp. 4510-4515.

[173] P.P. Wong, F. Miranda, K.V. Chan, C. Berlato, H.C. Hurst, A.G. Scibetta. Histone demethylase KDM5B collaborates with TFAP2C and Myc to repress the cell cycle inhibitor p21(cip) (CDKN1A) Mol Cell Biol, 32 (2012), pp. 1633-1644.

[174] M. Inomata, H. Tagawa, Y.M. Guo, Y. Kameoka, N. Takahashi, K. Sawada. MicroRNA-1792 down-regulates expression of distinct targets in different B-cell lymphoma subtypes Blood, 113 (2009), pp. 396-402.

[175] P. Wong, M. Iwasaki, T.C. Somervaille, F. Ficara, C. Carico, C. Arnold, C.Z. Chen, M.L. Cleary. The miR-17-92 microRNA polycistron regulates MLL leukemia stem cell potential by modulating p21 expression Cancer Res, 70 (2010), pp. 3833-3842.

[176] J. Vlach, S. Hennecke, K. Alevizopoulos, D. Conti, B. Amati. Growth arrest by the cyclindependent kinase inhibitor p27Kip1 is abrogated by c-Myc Embo J, 15 (1996), pp. 6595-6604.

[177] J.C. Acosta, N. Ferrandiz, G. Bretones, V. Torrano, R. Blanco, C. Richard, B. O'Connell, J. Sedivy, M.D. Delgado, J. Leon. Myc inhibits p27-induced erythroid differentiation of leukemia cells by repressing erythroid master genes without reversing p27-mediated cell cycle arrest Mol Cell Biol, 28 (2008), pp. 7286-7295.

[178] W. Yang, J. Shen, M. Wu, M. Arsura, M. FitzGerald, Z. Suldan, D.W. Kim, C.S. Hofmann, S. Pianetti, R. Romieu-Mourez, L.P. Freedman, G.E. Sonenshein. Repression of transcription of the p27(Kip1) cyclin-dependent kinase inhibitor gene by c-Myc Oncogene, 20 (2001), pp. 1688-1702.

[179] V. Chandramohan, N.D. Mineva, B. Burke, S. Jeay, M. Wu, J. Shen, W. Yang, S.R. Hann, G.E. Sonenshein. C-Myc represses FOXO3a-mediated transcription of the gene encoding the p27(Kip1) cyclin dependent kinase inhibitor J Cell Biochem, 104 (2008), pp. 2091-2106.

[180] P. Pineau, S. Volinia, K. McJunkin, A. Marchio, C. Battiston, B. Terris, V. Mazzaferro, S.W. Lowe, C.M. Croce, A. Dejean. miR-221 overexpression contributes to liver tumorigenesis Proc Natl Acad Sci U S A, 107 (2010), pp. 264-269.

[181] T.J. Soos, H. Kiyokawa, J.S. Yan, M.S. Rubin, A. Giordano, A. DeBlasio, S. Bottega, B. Wong, J. Mendelsohn, A. Koff. Formation of p27-CDK complexes during the human mitotic cell cycle Cell Growth Differ, 7 (1996), pp. 135-146.

[182] A.J. Obaya, J.M. Sedivy. Regulation of cyclin-Cdk activity in mammalian cells Cell Mol Life Sci, 59 (2002), pp. 126-142.

[183] R.C. O'Hagan, M. Ohh, G. David, I.M. de Alboran, F.W. Alt, W.G. Kaelin, Jr., R.A. DePinho. Myc-enhanced expression of Cul1 promotes ubiquitin-dependent proteolysis and cell cycle progression Genes Dev, 14 (2000), pp. 2185-2191.

[184] U.B. Keller, J.B. Old, F.C. Dorsey, J.A. Nilsson, L. Nilsson, K.H. MacLean, L. Chung, C. Yang, C. Spruck, K. Boyd, S.I. Reed, J.L. Cleveland. Myc targets Cks1 to provoke the suppression of p27Kip1, proliferation and lymphomagenesis Embo J, 26 (2007), pp. 25622574.

[185] G. Bretones, J.C. Acosta, J.M. Caraballo, N. Ferrandiz, M.T. Gomez-Casares, M. Albajar, R. Blanco, P. Ruiz, W.C. Hung, M.P. Albero, I. Perez-Roger, J. Leon. SKP2 oncogene is a direct MYC target gene and MYC down-regulates p27(KIP1) through SKP2 in human leukemia cells J Biol Chem, 286 (2011), pp. 9815-9825. 
[186] A. Montagnoli, F. Fiore, E. Eytan, A.C. Carrano, G.F. Draetta, A. Hershko, M. Pagano. Ubiquitination of p27 is regulated by Cdk-dependent phosphorylation and trimeric complex formation Genes Dev, 13 (1999), pp. 1181-1189.

[187] A.C. Carrano, E. Eytan, A. Hershko, M. Pagano. SKP2 is required for ubiquitin-mediated degradation of the CDK inhibitor p27 Nat Cell Biol, 1 (1999), pp. 193-199.

[188] L.M. Tsvetkov, K.H. Yeh, S.J. Lee, H. Sun, H. Zhang. p27(Kip1) ubiquitination and degradation is regulated by the SCF(Skp2) complex through phosphorylated Thr187 in p27 Curr Biol, 9 (1999), pp. 661-664.

[189] H. Sutterluty, E. Chatelain, A. Marti, C. Wirbelauer, M. Senften, U. Muller, W. Krek. p45SKP2 promotes p27Kip1 degradation and induces $S$ phase in quiescent cells Nat Cell Biol, 1 (1999), pp. 207-214.

[190] D. Muller, C. Bouchard, B. Rudolph, P. Steiner, I. Stuckmann, R. Saffrich, W. Ansorge, W. Huttner, M. Eilers. Cdk2-dependent phosphorylation of p27 facilitates its Myc-induced release from cyclin E/cdk2 complexes Oncogene, 15 (1997), pp. 2561-2576.

[191] K. Nakayama, H. Nagahama, Y.A. Minamishima, S. Miyake, N. Ishida, S. Hatakeyama, M. Kitagawa, S. lemura, T. Natsume, K.I. Nakayama. Skp2-mediated degradation of p27 regulates progression into mitosis Dev Cell, 6 (2004), pp. 661-672.

[192] U. Kossatz, N. Dietrich, L. Zender, J. Buer, M.P. Manns, N.P. Malek. Skp2-dependent degradation of p27kip1 is essential for cell cycle progression Genes Dev, 18 (2004), pp. 26022607.

[193] I.M. Chu, L. Hengst, J.M. Slingerland. The Cdk inhibitor p27 in human cancer: prognostic potential and relevance to anticancer therapy Nat Rev Cancer, 8 (2008), pp. 253-267.

[194] I. Nickeleit, S. Zender, U. Kossatz, N.P. Malek. p27kip1: a target for tumor therapies? Cell Div, 2 (2007), pp. 13.

[195] K. Berns, C. Martins, J.H. Dannenberg, A. Berns, H. te Riele, R. Bernards. p27kip1independent cell cycle regulation by MYC Oncogene, 19 (2000), pp. 4822-4827.

[196] S.M. Iguchi-Ariga, T. Itani, Y. Kiji, H. Ariga. Possible function of the c-myc product: promotion of cellular DNA replication EMBO J, 6 (1987), pp. 2365-2371.

[197] D. Dominguez-Sola, C.Y. Ying, C. Grandori, L. Ruggiero, B. Chen, M. Li, D.A. Galloway, W. Gu, J. Gautier, R. Dalla-Favera. Non-transcriptional control of DNA replication by c-Myc Nature, 448 (2007), pp. 445-451.

[198] S.V. Srinivasan, D. Dominguez-Sola, L.C. Wang, O. Hyrien, J. Gautier. Cdc45 is a critical effector of myc-dependent DNA replication stress Cell Rep, 3 (2013), pp. 1629-1639.

[199] Q. Li, C.V. Dang. c-Myc overexpression uncouples DNA replication from mitosis Mol Cell Biol, 19 (1999), pp. 5339-5351.

[200] S. Herold, B. Herkert, M. Eilers. Facilitating replication under stress: an oncogenic function of MYC? Nat Rev Cancer, 9 (2009), pp. 441-444.

[201] T.I. Kuschak, B.C. Kuschak, C.L. Taylor, J.A. Wright, F. Wiener, S. Mai. c-Myc initiates illegitimate replication of the ribonucleotide reductase R2 gene Oncogene, 21 (2002), pp. 909920.

[202] M. Albajar, M.T. Gomez-Casares, J. Llorca, I. Mauleon, J.P. Vaque, J.C. Acosta, A. Bermudez, N. Donato, M.D. Delgado, J. Leon. MYC in chronic myeloid leukemia: induction of aberrant DNA synthesis and association with poor response to imatinib Mol Cancer Res, 9 (2011), pp. 564-576.

[203] M.J. Munoz-Alonso, L. Ceballos, G. Bretones, P. Frade, J. Leon, A. Gandarillas. MYC accelerates p21CIP-induced megakaryocytic differentiation involving early mitosis arrest in leukemia cells J Cell Physiol, 227 (2012), pp. 2069-2078.

[204] J. Wang, L.Y. Xie, S. Allan, D. Beach, G.J. Hannon. Myc activates telomerase Genes Dev, 12 (1998), pp. 1769-1774.

[205] C. Cerni. Telomeres, telomerase, and myc. An update Mutat Res, 462 (2000), pp. 31-47. [206] G.J. Kops, B.A. Weaver, D.W. Cleveland. On the road to cancer: aneuploidy and the mitotic checkpoint Nat Rev Cancer, 5 (2005), pp. 773-785.

[207] I. Primorac, A. Musacchio. Panta rhei: the APC/C at steady state J Cell Biol, 201 (2013), pp. 177-189.

[208] A. Menssen, A. Epanchintsev, D. Lodygin, N. Rezaei, P. Jung, B. Verdoodt, J. Diebold, H. Hermeking. C-MYC delays prometaphase by direct transactivation of MAD2 and BubR1: identification of mechanisms underlying C-MYC-induced DNA damage and chromosomal instability Cell Cycle, 6 (2007), pp. 339-352.

[209] M. Wade, G.M. Wahl. c-Myc, genome instability, and tumorigenesis: the devil is in the details Curr Top Microbiol Immunol, 302 (2006), pp. 169-203. 
[210] E.V. Prochownik. c-Myc: linking transformation and genomic instability Curr Mol Med, 8 (2008), pp. 446-458.

[211] A. Goga, D. Yang, A.D. Tward, D.O. Morgan, J.M. Bishop. Inhibition of CDK1 as a potential therapy for tumors over-expressing MYC Nat Med, 13 (2007), pp. 820-827.

[212] D. Horiuchi, L. Kusdra, N.E. Huskey, S. Chandriani, M.E. Lenburg, A.M. Gonzalez-Angulo, K.J. Creasman, A.V. Bazarov, J.W. Smyth, S.E. Davis, P. Yaswen, G.B. Mills, L.J. Esserman, A. Goga. MYC pathway activation in triple-negative breast cancer is synthetic lethal with CDK inhibition J Exp Med, 209 (2012), pp. 679-696.

[213] Q.M. Guo, R.L. Malek, S. Kim, C. Chiao, M. He, M. Ruffy, K. Sanka, N.H. Lee, C.V. Dang, E.T. Liu. Identification of c-myc responsive genes using rat cDNA microarray Cancer Res, 60 (2000), pp. 5922-5928.

[214] B.C. O'Connell, A.F. Cheung, C.P. Simkevich, W. Tam, X. Ren, M.K. Mateyak, J.M. Sedivy. A large scale genetic analysis of c-Myc-regulated gene expression patterns $\mathrm{J}$ Biol Chem, (2003), pp.

[215] G. Leone, J. DeGregori, R. Sears, L. Jakoi, J.R. Nevins. Myc and Ras collaborate in inducing accumulation of active cyclin E/Cdk2 and E2F Nature, 387 (1997), pp. 422-426.

[216] D.Y. Mao, J.D. Watson, P.S. Yan, D. Barsyte-Lovejoy, F. Khosravi, W.W. Wong, P.J. Farnham, T.H. Huang, L.Z. Penn. Analysis of Myc Bound Loci Identified by CpG Island Arrays Shows that Max Is Essential for Myc-Dependent Repression Curr Biol, 13 (2003), pp. 882-886. [217] V. Chandramohan, S. Jeay, S. Pianetti, G.E. Sonenshein. Reciprocal control of Forkhead box $\mathrm{O} 3 \mathrm{a}$ and $\mathrm{c}-\mathrm{Myc}$ via the phosphatidylinositol 3-kinase pathway coordinately regulates p27Kip1 levels J Immunol, 172 (2004), pp. 5522-5527.

[218] P. Staller, K. Peukert, A. Kiermaier, J. Seoane, J. Lukas, H. Karsunky, T. Moroy, J. Bartek, J. Massague, F. Hanel, M. Eilers. Repression of p15INK4b expression by Myc through association with Miz-1 Nat Cell Biol, 3 (2001), pp. 392-399.

[219] J. Seoane, C. Pouponnot, P. Staller, M. Schader, M. Eilers, J. Massague. TGFbeta influences Myc, Miz-1 and Smad to control the CDK inhibitor p15INK4b Nat Cell Biol, 3 (2001), pp. 400-408. 
Table 1. Myc target genes involved in cell cycle. ChIP, chromatin immunoprecipitation; ChIP-onchip, ChIP followed by analysis by chip microarray of the immunoprecipitated chromatin/DNA; ChIP-seq, ChIP followed by sequencing of the immunoprecipitated chromatin/DNA ChIP-PET, ChiP coupled with pair-ends tag sequencing. Human gene nomenclatura is used.

\begin{tabular}{|c|c|c|c|}
\hline $\begin{array}{l}\text { Target } \\
\text { gene }\end{array}$ & $\begin{array}{l}\text { Myc effect } \\
\text { on } \\
\text { expression }\end{array}$ & Cells & $\begin{array}{l}\text { Myc bound to promoter } \\
\text { Method } / \text { Cells }\end{array}$ \\
\hline \multirow{2}{*}{$\begin{array}{l}\text { CCND1 } \\
\text { (Cyclin D1) }\end{array}$} & Induced & Rodent fibroblasts [139-141] & \multirow{2}{*}{ ChIP-on-ChIP / mouse ES cells [107] } \\
\hline & Repressed & Rodent fibroblasts $[132,142,143,213]$ & \\
\hline $\begin{array}{c}\text { CCND2 } \\
\text { (Cyclin D2) }\end{array}$ & Induced & $\begin{array}{l}\text { Rodent fibroblasts }[139,140,145,146] \\
\text { Human primary fibroblasts }[99]\end{array}$ & $\begin{array}{c}\text { Reporter assays / mouse fibroblasts } \\
\text { [145] } \\
\text { ChIP / mouse fibroblasts and human } \\
\text { myeloid cells (HL60) [146] } \\
\text { ChIP-PET / human B cells (P493.6) [101] }\end{array}$ \\
\hline $\begin{array}{c}\text { CCND3 } \\
\text { (Cyclin D3) }\end{array}$ & Induced & $\begin{array}{l}\text { Mouse embryonic fibroblasts [140] } \\
\text { Human embryonic lung fibroblasts and human } \\
\text { lung carcinoma epithelial cells [135] }\end{array}$ & ChIP-PET / human B cells (P493.6) [101] \\
\hline $\begin{array}{l}\text { CCNE1 } \\
\text { (Cyclin E1) }\end{array}$ & Induced & Rat fibroblasts $[103,131]$ & ChIP-PET / human B cells (P493.6) [101] \\
\hline $\begin{array}{l}\text { CCNE2 } \\
\text { (Cyclin E2) }\end{array}$ & Induced & $\begin{array}{l}\text { Human embryonic lung fibroblasts (HEL) and } \\
\text { human lung carcinoma epithelial cells (A549) } \\
\text { [135] }\end{array}$ & $\begin{array}{l}\text { ChIP-PET / human B cells (P493.6) [101] } \\
\text { ChIP-on-ChIP / human cervical } \\
\text { carcinoma cells (HeLa) [134] } \\
\text { ChIP-on-ChIP / mouse ES cells [107] }\end{array}$ \\
\hline $\begin{array}{l}\text { CCNA2 } \\
\text { (Cyclin A) }\end{array}$ & Induced & $\begin{array}{c}\text { Rat fibroblasts [132, 136, 142, 148, 149] } \\
\text { Human embryonic lung fibroblasts (HEL) and } \\
\text { human lung carcinoma epithelial cells (A549) } \\
{[135]}\end{array}$ & ChIP-on-ChIP / human HeLa cells [134] \\
\hline $\begin{array}{l}\text { CCNB1 } \\
\text { (cyclin B1) }\end{array}$ & Induced & $\begin{array}{c}\text { Mouse myeloid cells (32D) and rat fibroblasts } \\
\text { [151] } \\
\text { Human umbilical vein endothelial cells (HUVEC) } \\
\text { [85] and human lung cancer cells (NCl-H460) } \\
{[150]}\end{array}$ & $\begin{array}{l}\text { ChIP/ human lung cancer cells [150] } \\
\text { ChIP and ChIP-on-ChIP / Human HeLa } \\
\text { cells [85, 134] } \\
\text { ChIP-on-ChIP / mouse ES cells [107] }\end{array}$ \\
\hline$C D K 1$ & Induced & $\begin{array}{c}\text { Mouse pro-B cells (BAF-B03) [137] } \\
\text { Rat fibroblast }[138,213]\end{array}$ & ChIP-on-ChIP / mouse ES cells [107] \\
\hline \multirow[t]{2}{*}{$C D K 2$} & Induced & $\begin{array}{l}\text { Human embryonic lung fibroblasts (HEL) and } \\
\text { human lung carcinoma epithelial cells (A549) } \\
{[135]}\end{array}$ & \multirow[t]{2}{*}{ - } \\
\hline & Repressed & Rat fibroblasts [103] & \\
\hline$C D K 4$ & Induced & $\begin{array}{c}\text { Rodent fibroblasts }[103,104,133,213,214] \\
\text { Human umbilical vein endothelial cells (HUVEC) } \\
{[85,133]}\end{array}$ & $\begin{array}{c}\text { ChIP-PET / human B cells (P493.6) [101] } \\
\text { ChIP and ChIP-on-ChIP/ human cervical } \\
\text { carcinoma cells (HeLa) [85, 134] } \\
\text { ChIP-seq / human Burkitt lymphoma } \\
\text { cells (Raji, CA46, Blue1,BL41 and } \\
\text { Ramos) [111] } \\
\text { ChIP-on-ChIP and ChIP-seq / mouse ES } \\
\text { cells [95, 106] } \\
\text { ChIP-seq / mouse fibroblast [104] }\end{array}$ \\
\hline$C D K 6$ & Induced & Rat fibroblasts [103] & $\begin{array}{c}\text { ChIP-on-ChIP / human Burkitt lymphoma } \\
\text { cells (Daudi) [108] } \\
\text { ChIP-on-ChIP / human cervical } \\
\text { carcinoma cells (HeLa) [134] } \\
\text { ChIP-on-ChIP / mouse ES cells [106, } \\
107]\end{array}$ \\
\hline CDK7 & Induced & $\begin{array}{l}\text { Human epithelial cells [155] and rat fibroblasts } \\
{[89,155,156] .}\end{array}$ & $\begin{array}{l}\text { ChIP-on-ChIP and ChIP-seq / Mouse ES } \\
\text { cells }[95,106,107]\end{array}$ \\
\hline$C D C 25 A$ & Induced & Rodent fibroblats $[103,163]$ & $\begin{array}{l}\text { ChIP-on-ChIP/ human cervical } \\
\text { carcinoma cells (HeLa) [134] }\end{array}$ \\
\hline E2F1 & Induced & Mouse $B$ cells $[184]$ and rat fibroblast $[118,215]$ & $\begin{array}{l}\text { ChIP / human myeloid cells (U-937 and } \\
\text { HL60), human B cells (P493.6), human } \\
\text { glioblastoma (T98G), human skin } \\
\text { fibroblasts (WS1) [105] }\end{array}$ \\
\hline \multirow[b]{2}{*}{ E2F2 } & Repressed & Rat fibroblast [103] & \multirow{2}{*}{$\begin{array}{l}\text { ChIP-Seq, ENCODE project, } \\
\text { (http://genome.ucsc.edu/) }\end{array}$} \\
\hline & Induced & Rat fibroblasts [119] & \\
\hline E2F3 & Induced & Rat fibroblasts $[103,118]$ & ChIP-on-ChIP / mouse ES cells [107] \\
\hline
\end{tabular}




\begin{tabular}{|c|c|c|c|}
\hline $\begin{array}{l}C D K N 1 A \\
(p 21)\end{array}$ & Repressed & $\begin{array}{l}\text { Mouse fibroblast [104, 164] } \\
\text { Human primary fibroblasts (WI-38) [99]; human } \\
\text { embryonic lung fibroblasts (HEL) and human } \\
\text { lung carcinoma epithelial cells (A549) [135]; } \\
\text { human keratinocytes [164]; human colon } \\
\text { carcinoma cells (HCT116) [167] and human } \\
\text { myeloid cell lines (U-937, HL60 and K562) [168] }\end{array}$ & $\begin{array}{c}\text { ChIP/ rat fibroblasts [216] } \\
\text { ChIP / human myeloid cells (U-937 and } \\
\text { HL60) [168] } \\
\text { ChIP-PET / human B cells (P493.6) [101] } \\
\text { ChIP-on-ChIP / human cervical } \\
\text { carcinoma cells (HeLa) [134] }\end{array}$ \\
\hline $\begin{array}{l}C D K N 1 B \\
(\mathrm{p} 27)\end{array}$ & Repressed & $\begin{array}{c}\text { Mouse B cells (WEHI 231) [178, 217] } \\
\text { Rat fibroblasts [103] } \\
\text { Human T cells (Jurkat) and human breast cancer } \\
\text { cells (Hs578T) [178]; human embryonic lung } \\
\text { fibroblasts (HEL) and human lung carcinoma } \\
\text { epithelial cells (A549) [135] }\end{array}$ & $\begin{array}{c}\text { Reporter assays / human T cells (Jurkat) } \\
\text { [178] } \\
\text { ChIP-on-ChIP/ human Burkitt lymphoma } \\
\text { cells (Daudi) [108] }\end{array}$ \\
\hline $\begin{array}{l}C D K N 2 B \\
(p 15)\end{array}$ & Repressed & $\begin{array}{c}\text { Rat [218] and mouse fibroblasts [104] } \\
\text { Human keratinocytes [219] }\end{array}$ & $\begin{array}{l}\text { ChIP / human myeloid cells (HL60) and } \\
\text { rat fibroblasts [216] } \\
\text { ChIP-PET/ human B cells (P493.6) [101] }\end{array}$ \\
\hline
\end{tabular}

\section{Figure Legends}

Figure 1. Myc stimulates the cell cycle progression.

Schematic representation of the cell cycle phases, the main cell cycle regulators and how Myc influence the cell cycle through the induction or repression of target genes encoding many of those regulators. The cell cycle progression is mainly regulated by the sequential action of cyclin-Cdk complexes that induce the correct progression through the cell cycle phases. Activated Cdks phosphorylate different substrates including the retinoblastoma protein $(\mathrm{Rb})$. Such mechanism allows the activation of the E2F transcription factors which transactivate target genes related to DNA synthesis. Different Cdk inhibitors such as p15, p16, p21 or p27 inhibit cyclin-Cdk complexes. Myc induces the expression of several positive regulators of the cell cycle while represses cell cycle inhibitors by different mechanisms (see text for details). As a consequence, Myc stimulates the cell cycle progression and the cellular proliferation.

Figure 2. Mechanisms for Myc-mediated antagonism of p21 (A) and p27 (B). Myc stimulates cell proliferation through its ability to antagonize p21 and p27 expression and activities. This is accomplished by different direct and indirect mechanisms, as schematized in the figure. See Sections 7 and 8 for details 


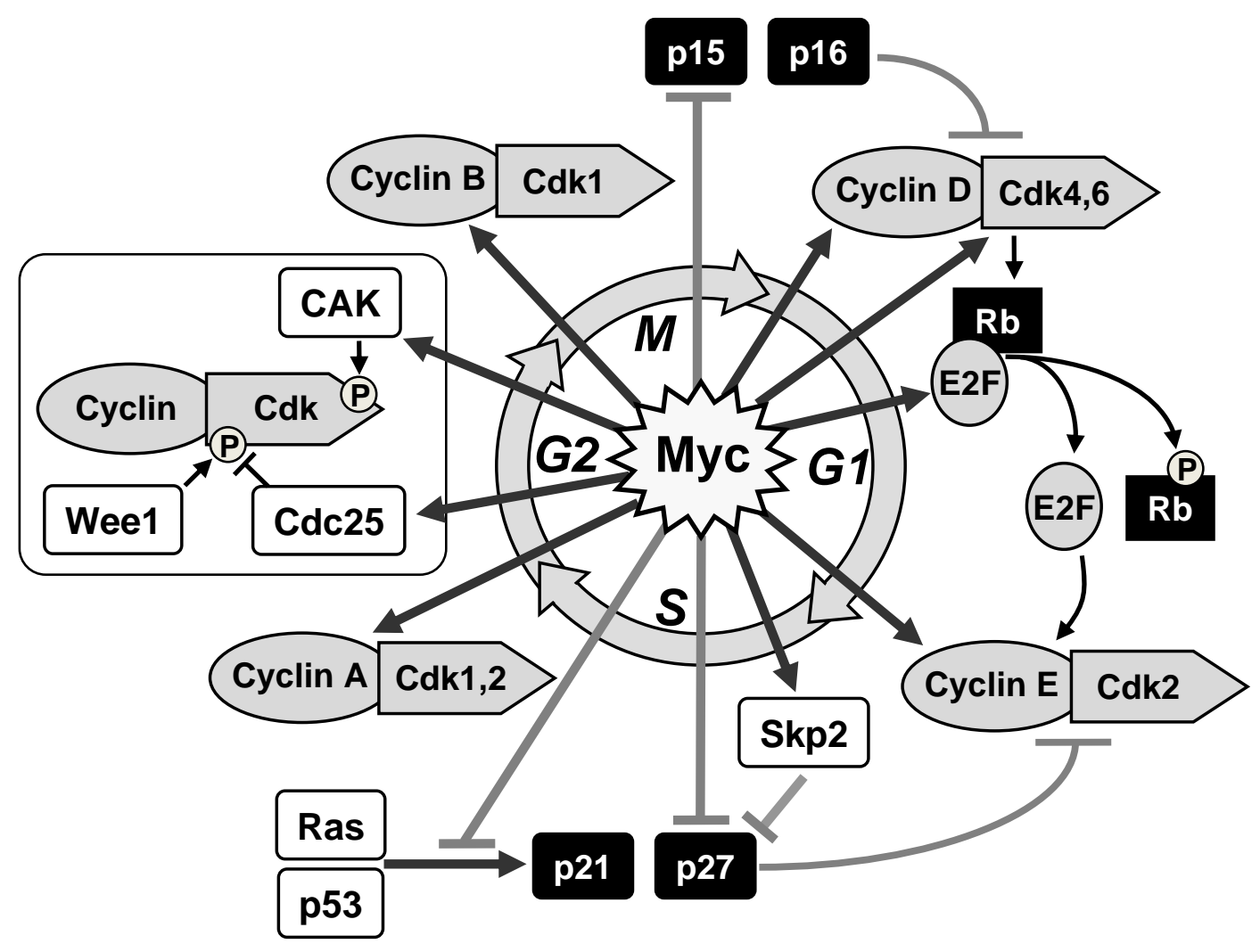


A
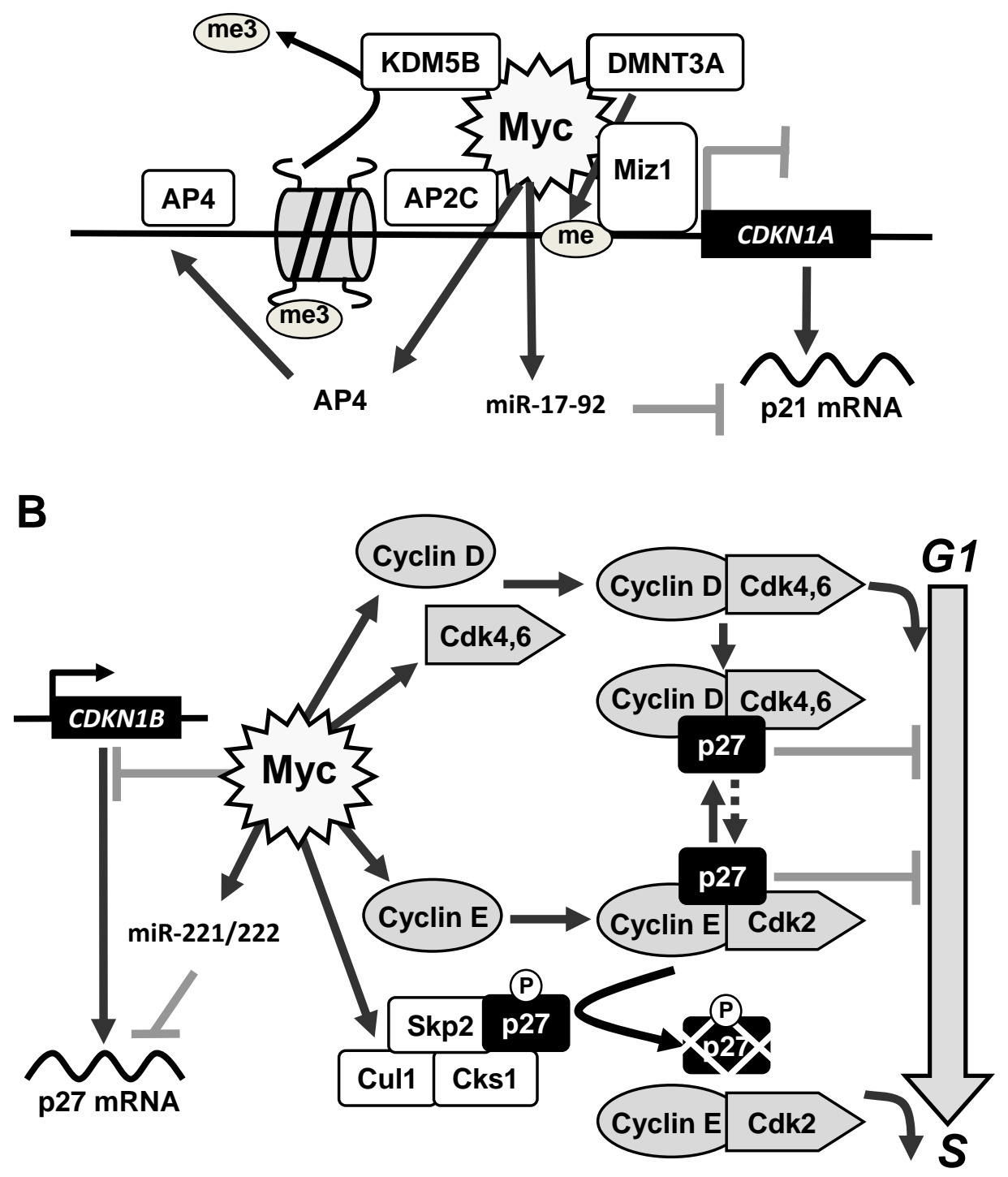